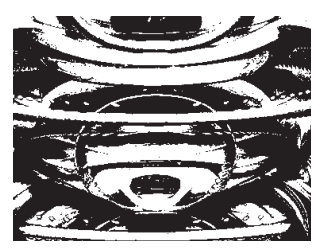

\title{
PROMJENE U DINAMIČKIM OBILJEŽJIMA NASELJENOSTI OTOKA KRKA
}

Marta JOVANIĆ

Vinkovci

Ivo TURK

Institut društvenih znanosti Ivo Pilar, Zagreb

UDK: $314.8(210.7$ Krk)"1857/2011"

Prethodno priopćenje

Primljeno: 22. 12. 2012.

Razvoi naseljenosti otoka uvjetovan je ponajviše udaljenošću od kopna i načinom prometnoga povezivanja. Otok Krk je danas sa zaleđem povezan mostom i zračnim linijama, a s ostalim otocima trajektnim linijama. Cili je rada istražiti i objasniti dinamiku određenih demografskih komponenti na otoku. $U$ radu se promatra promiena naseljenosti otoka Krka od 1857. do 2011. godine (razdoblje između prvoga i najnovijega popisa stanovništva). Utvrđeno je da je smanjenje broja stanovnika od početka 20. stoljeća povezano s procesima urbanizacije Rijeke, dok je povećanje broja stanovnika otoka od sedamdesetih godina 20. stoljeća povezano s procesom suburbanizacije istoga grada, na što je znatno utjecala izgradnja Krčkog mosta. Od sedamdesetih godina 20. stoljeća do danas zapadna i sjeverna strana otoka bilieže pozitivnije demografske pokazatelje od istočne i jugoistočne strane. To se može objasniti boljim preduvietima za razvoj turizma na zapadnoj strani otoka te razvojem industrije i većom blizinom Rijeke. Stoga od sredine 19. stoljeća do danas pratimo premieštanje težišta naseljenosti otoka u smjeru sjeverozapada, a u skladu s tim je i elipsa naseljenosti za 2011. položena sjeverozapadnije nego ona za 1857. godinu.

Ključne riječi: naseljenost, težište naseljenosti, otok Krk, demografska dinamika, elipsa stanovništva, litoralizacija

$\triangle$ Marta Jovanić, M. A. Relikovića 5, 32100 Vinkovci.

E-mail: marta.jovanic@gmail.com

\section{UVOD}

Razvoj naseljenosti otoka uvjetovan je ponajviše udaljenošću od kopna i načinom povezivanja s kopnom. Svaki je otok po svojoj prirodi izoliran - morem je odvojen od susjednoga kop- 
DRUŠ. ISTRAŽ. ZAGREB GOD. 22 (2013), BR. 1, STR. 167-193

JOVANIĆ, M., TURK, I.: PROMJENE U... na i drugih otoka. Ta prirodna izoliranost oduvijek je imala velik utjecaj na specifične uvjete života otočnoga stanovništva, odnosno cjelokupan društveni i gospodarski razvoj otoka. Ovisno o udaljenosti od kopna te načinu povezivanja otoka s kopnom (most, brodska linija), stupanj izoliranosti otoka se razlikuje (Stražičić, 1977). Otok Krk pripada priobalnim otocima. ${ }^{1} \mathrm{~S}$ obzirom na činjenicu da je s kopnom povezan mostom, trajektnom i zračnom linijom, ima veliku interakciju s kopnom i u kretanju stanovništva i u bržem prihvaćanju raznih procesa (vanjske migracije stanovništva, litoralizacija).

U ovom se radu promatra promjena $u$ dinamičkim obilježjima naseljenosti otoka Krka od 1857. do 2011. godine, između prvoga i zadnjega popisa stanovništva. Popisna se promjena broja stanovnika promatra na temelju 16 popisa stanovništva, koliko ih je provedeno u tom razdoblju. Prirodno kretanje stanovništva razmatra se tek od 1964. godine, jer se vitalna statistika na razini naselja u Hrvatskoj ranije nije vodila. Na temelju spomenutih podataka mogu se uočiti promjene u naseljenosti na otoku Krku koje su uvjetovane društveno-gospodarskim procesima i događajima.

Predmet istraživanja ovog rada jest analiza promjena naseljenosti otoka Krka od prvoga popisa stanovništva do zadnjega od 1857. do 2011. Neki se procesi (npr. kretanje broja stanovnika, veličina naselja, pomicanje težišta naseljenosti, elipsa stanovništva) mogu pratiti od 1857. do 2011. godine. Vitalna je statistika prikazana od 1964. zbog toga što se ona od tada sustavno vodi na razini naselja. Migracijska kretanja otoka Krka objašnjena su od druge polovice 19. stoljeća. Za 2001. godinu detaljnije je analizirana migracija stanovništva. Cilj je rada istražiti i objasniti promjene u dinamici stanovništva na otoku Krku.

\section{METODOLOŠKE NAPOMENE}

Otok Krk je podijeljen na sedam jedinica lokalne samouprave - jedan (administrativni) grad i šest općina. To su: Grad Krk i općine: Baška, Dobrinj, Malinska-Dubašnica, Omišalj, Punat i Vrbnik. Ukupno je na otoku Krku 68 naselja (Slika 1).

Uzimajući u obzir da se u svjetskim razmjerima radi o relativno malom otoku, posebno je zanimljivo bilo definirati naselja na obali i naselja unutrašnjosti. U literaturi postoje dvije podjele, a u ovom smo se radu odlučili za onu novijega datuma autora Lajića i Mišetića (2006). Autorica P. Novosel-Žic (1987) od 68 naselja otoka Krka 14 smatra priobalnima, dok za ostala 54 smatra da su se razvila u unutrašnjosti otoka. Razlika podjele jest u naselju Zidarići (općina Malinska-Dubašnica), jer je ono svojim razvojem u zadnjih dvadesetak godina postalo priobalno. Tako je u ovom radu definirano 15 naselja na obali i 53 naselja u unutrašnjosti otoka Krka. 


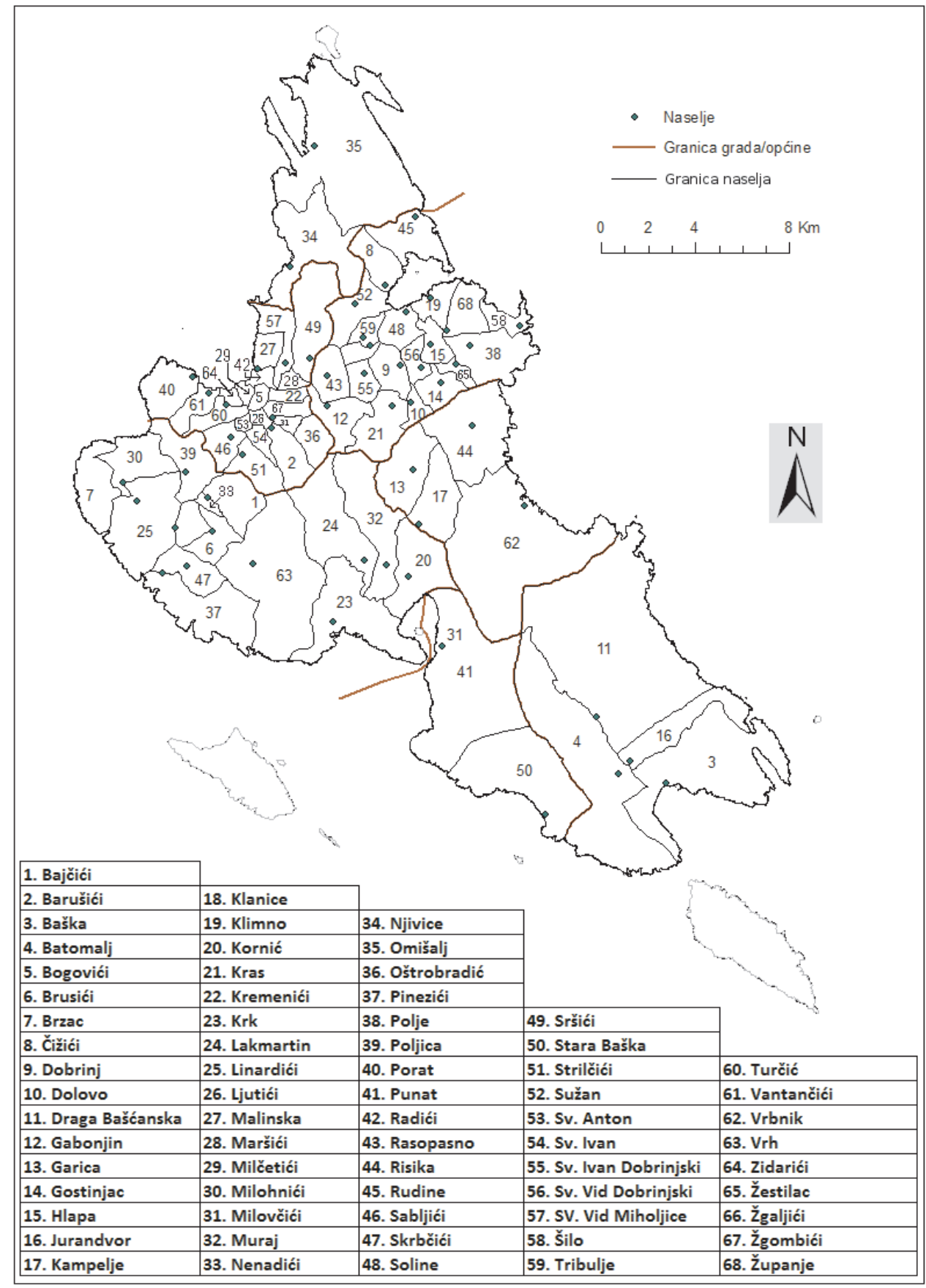

i SLIKA 1

Administrativno-teritorijalna podjela otoka Krka na gradove/općine i naselja
U analizi demografskih pokazatelja pojedinih popisa stanovništva javljaju se određene metodološke razlike zbog različitih popisnih koncepcija. Naime, popisi iz 1857., 1948., 1953., 1961., 1971., 1981. i 1991. provedeni su prema koncepciji stal- 
DRUŠ. ISTRAŽ. ZAGREB GOD. 22 (2013), BR. 1, STR. 167-193

JOVANIĆ, M., TURK, I.: PROMJENE U... noga stanovništva (tzv. de iure stanovništvo), a popisi iz 1869. 1880., 1890., 1900., 1910., 1921. i 1931. prema koncepciji prisutnoga stanovništva (tzv. de facto stanovništvo) (Pokos, 2003). Popisi iz 2001. i 2011. provedeni su prema koncepciji uobičajenoga mjesta stanovanja (eng. place of usual residence). ${ }^{2}$ Imajući na umu nekonzistentnost popisne metodologije navedenih 16 popisa stanovništva, dobiveni podaci o stanovništvu nisu potpuno usporedivi. Kako je namjera što vjernije prikazati generalne trendove promjena naseljenosti otoka Krka, službeni su podaci Državnoga zavoda za statistiku za razdoblje od 1857. do 2001. u seriji knjiga Stanovništvo hrvatskih otok $a^{3}$ ponešto promijenjeni i prilagođeni. Ti su podaci u radu smatrani mjerodavnima. ${ }^{4}$ Uzeti su i rezultati popisa stanovništva iz 2011. godine, preuzeti sa službenih internetskih stranica Državnoga zavoda za statistiku.

Podaci vitalne statistike dostupni su od 1964. godine. Kao izvor za njih upotrijebljeni su tablogrami Vitalne statistike DZS-a.

Podaci o migraciji stanovništva na otoku Krku razmatrani su za popis stanovništva za 2001. godinu, jer u vrijeme pisanja rada podaci za 2011. još nisu bili objavljeni.

\section{DOSADAŠNJA ISTRAŽIVANJA}

Otok Krk bio je predmetom istraživanja mnogih geografa i demografa. Mnoge znanstvene radove na temu razvoja naseljenosti otoka Krka, a većina njih su i citirani u ovom radu, napisala je Petrica Novosel-Žic (1972, 1975, 1976, 1986, 1987). Istraživanjem otoka Krka, posebice njegova turizma, bavili su se H. Turk i V. T. Opačić. Konzultirani su i citirani i radovi kojima je tematika naseljenost ostalih hrvatskih otoka: Stražičić (1977), Nejašmić (1992, 1999), Lajić (2006) i Lajić i Mišetić (2006). Unatoč brojnim dosadašnjim istraživanjima, do sada se nitko nije bavio GIS analizom promjena u dinamičkim obilježjima naseljenosti otoka Krka.

\section{POPISNO KRETANJE BROJA STANOVNIKA}

U pregledu popisnoga kretanja broja stanovnika otoka Krka od 1857. do 2011. godine uočavaju se tri intervala:

1) Interval porasta stanovništva 1857. - 1910.

2) Interval pada stanovništva 1910. - 1971.

3) Interval ponovnoga porasta stanovništva 1971. - 2011.

1) Između 1857. i 1910. svakim je popisom na razini cijelog otoka zabilježen rast broja stanovnika (Tablica 2 i Slika 3). Godine 1910. dosegnut je najveći broj stanovnika (21 259). Dakle, stanovništvo otoka Krka u ovom se razdoblju od 53 godine povećalo za 6022 stanovnika ili 39,5\%, tj. prosječno za 114 stanovnika na godinu. Budući da u cijelom tom razdoblju nema znat- 
DRUŠ. ISTRAŽ. ZAGREB GOD. 22 (2013), BR. 1 STR. 167-193

JOVANIĆ, M., TURK, I.: PROMJENE U...
(1) SLIKA 2

Kretanje broja stanovnika na otoku Krku od 1857.do 2011. nijeg useljavanja, može se zaključiti da je taj porast broja stanovnika na otoku Krku uvjetovan prirodnim priraštajem. To je razumljivo stoga što je tada stanovništvo otoka Krka ušlo $u$ proces demografske tranzicije. Zbog poboljšanja zdravstvene skrbi smanjuje se mortalitet, a demoreproduktivne navike još se neko vrijeme ne mijenjaju (natalitet ostaje visok). Demografska ekspanzija na otoku Krku polovicom 20. stoljeća pothranjivana je prije svega visokim, gotovo fiziološkim, natalitetom i odražava gospodarsku nerazvijenost, odnosno siromaštvo stanovništva (Novosel, 1976). Na temelju lančanog indeksa u promatranom periodu može se uočiti prilično ravnomjeran porast stanovništva. U međupopisnom razdoblju od 1880. do 1890. zabilježen je porast broja stanovnika od 9,9\%. U sljedećem međupopisju porast broja stanovnika smanjen je na $6,4 \%$. Smanjenje porasta odražava početke sporadične emigracije s otoka Krka uvjetovane propadanjem tada osnovnih ekonomskih djelatnosti - vinogradarstva i pomorstva. Minimalan porast od 0,6\% u međupopisnom razdoblju od 1900. do 1910. nagovještava suprotan proces u budućnosti (Novosel, 1975).

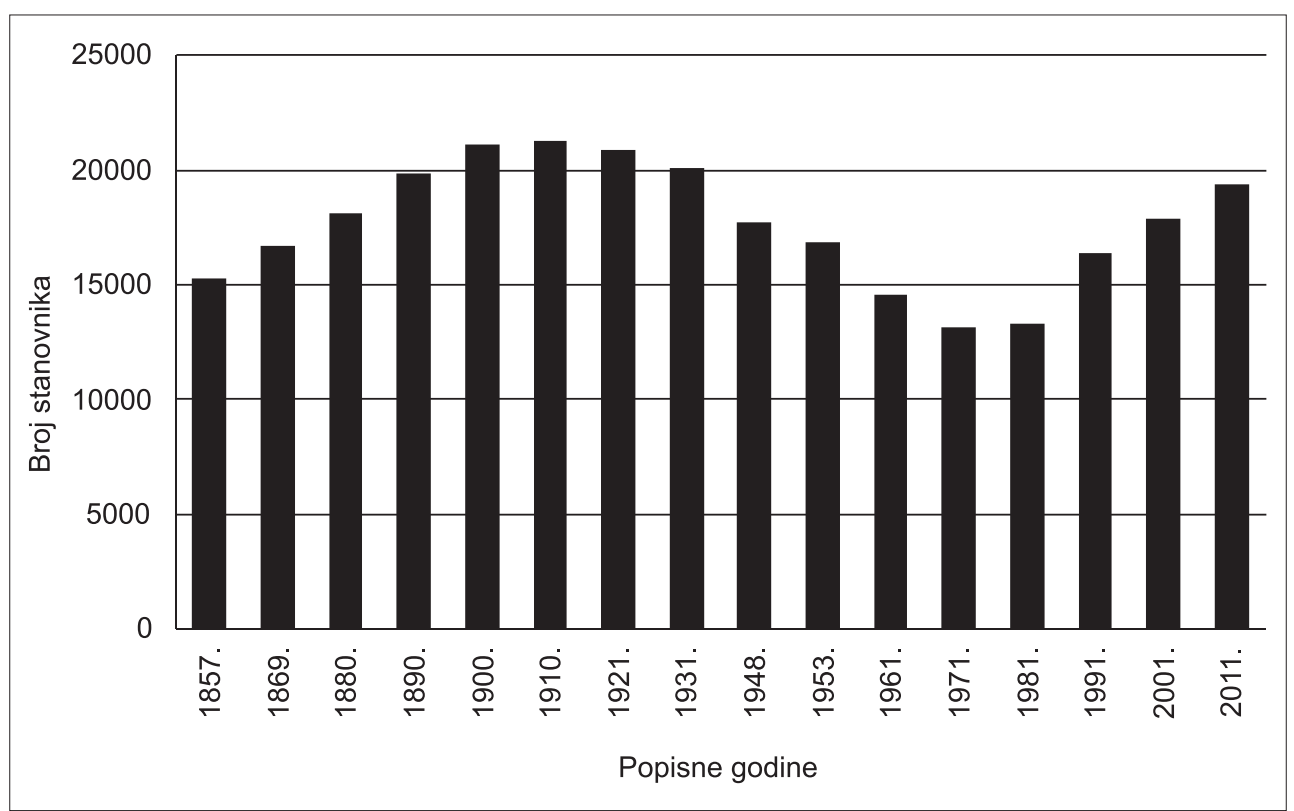

Izvor: Smoljanović, Smoljanović i Rudan (2008), Stanovništvo hrvatskih otoka 2001., Popis stanovništva, kućanstava i stanova 2011. (http://www.dzs.hr).

Detaljnijom analizom kretanja broja stanovnika mogu se uočiti razlike na razini (administrativnoga) grada i općina te na razini naselja. U ovom razdoblju svi su gradovi/općine bilježili porast broja stanovnika. Najveći porast broja stanovnika bio je u općinama Punat (za 86,1\%), Vrbnik (57,4\%) i Dobrinj $(48,3 \%)$. Porast apsolutnoga broja stanovnika uzrokovan je pri- 
DRUŠ. ISTRAŽ. ZAGREB GOD. 22 (2013), BR. 1, STR. 167-193

JOVANIĆ, M., TURK, I.: PROMJENE U...
(1) TABLICA 1

Kretanje ukupnoga broja stanovnika otoka Krka od 1857 do 2011. rodnim kretanjem stanovništva. U međupopisnom razdoblju od 1900. do 1910. u općinama Baška i Omišalj može se uočiti pad broja stanovnika uzrokovan već spomenutom emigracijom stanovništva, koja je posljedica propadanja vinogradarstva i pomorstva. Kretanje broja stanovnika na razini naselja u ovom je razdoblju većinom pozitivno, s različitim intenzitetom. Najveći porast od 99 stanovnika ili 128,6\% bilježi naselje Šilo. 5 U zapadnom dijelu otoka stanovništvo je u ovom razdoblju u velikoj mjeri obolijevalo i umiralo od malarije. Oskudica pitke vode prisiljavala je ljude da upotrebljavaju zagađenu vodu iz lokava, što je pogodovalo širenju zaraznih bolesti. S obzirom na to da je zdravstvena skrb tada bila na niskoj razini, zarazne su bolesti bile jedan od glavnih uzročnika umiranja stanovništva (Novosel, 1975).

\begin{tabular}{lrrrrr}
\hline Godina & Međupopisna \\
popisa & $\begin{array}{r}\text { Broj } \\
\text { promjena }\end{array}$ & $\begin{array}{r}\text { Prosječna } \\
\text { godišnja promjena } \\
\text { broja stanovnika }\end{array}$ & $\begin{array}{r}\text { Indeks } \\
(1857 .=100)\end{array}$ & $\begin{array}{r}\text { Lančani } \\
\text { indeks }\end{array}$ \\
\hline 1857. & 15237 & - & - & 100,0 & - \\
1869. & 16725 & 1488 & 124 & 109,8 & 109,8 \\
1880. & 18089 & 1364 & 124 & 118,7 & 108,2 \\
1890. & 19871 & 1782 & 178 & 130,4 & 109,9 \\
1900. & 21140 & 1269 & 127 & 138,7 & 106,4 \\
1910. & 21259 & 119 & 12 & 139,5 & 100,6 \\
1921. & 20842 & -417 & -38 & 136,8 & 98,0 \\
1931. & 20043 & -799 & -80 & 131,5 & 96,2 \\
1948. & 17689 & -2354 & -138 & 116,1 & 88,3 \\
1953. & 16820 & -869 & -174 & 110,4 & 95,1 \\
1961. & 14548 & -2272 & -284 & 95,5 & 86,5 \\
1971. & 13110 & -1438 & -144 & 86,0 & 90,1 \\
1981. & 13334 & 224 & 22 & 87,5 & 101,7 \\
1991. & 16402 & 3068 & 307 & 107,6 & 123,0 \\
2001. & 17860 & 1458 & 146 & 117,2 & 108,9 \\
2011. & 19383 & 1523 & 152 & 127,2 & 108,5 \\
\hline
\end{tabular}

Izvor: Smoljanović i sur. (2008), Stanovništvo hrvatskih otoka 2001., Popis stanovništva, kućanstava i stanova 2011. (http://www.dzs.hr).

2) Između 1910. i 1971. svakim je popisom na razini cijelog otoka zabilježen pad broja stanovnika (Tablica 3 i Slika 4). Godine 1971. zabilježen je najmanji broj stanovnika (13 110). U ovom razdoblju od 61 godine stanovništvo otoka Krka smanjilo se za 8149 stanovnika ili za 38,3\%, tj. prosječno za 134 stanovnika na godinu. U ovom razdoblju sve jedinice lokalne samouprave (grad / općina) bilježe pad broja stanovnika. Najveći pad imale su općine Baška (52,6\%), Omišalj $(45,9 \%)$ i Punat $(45,7 \%)$, a najmanji pad broja stanovnika imali su grad Krk 


\begin{tabular}{lrrrrrrr}
\hline $\begin{array}{l}\text { Grad/Općina/ } \\
\text { Općinsko sjedište }\end{array}$ & 1857. & 1869. & 1880. & 1890. & 1900. & 1910. & $1910 . / 1857$. \\
\hline Baška & 2881 & 3166 & 3310 & 3518 & 3711 & 3305 & 114,7 \\
$\quad$ Baška & 1811 & 1989 & 2050 & 2058 & 2047 & 1685 & 93,0 \\
Dobrinj & 2729 & 2977 & 3164 & 3468 & 3860 & 4046 & 148,3 \\
$\quad$ Dobrinj & 382 & 420 & 451 & 484 & 545 & 464 & 121,5 \\
Krk & 3117 & 3427 & 3531 & 3874 & 3902 & 4173 & 133,9 \\
$\quad$ Krk & 1440 & 1582 & 1592 & 1620 & 1648 & 1778 & 123,5 \\
Malinska-Dubašnica & 1704 & 1873 & 2000 & 2093 & 2120 & 2134 & 125,2 \\
$\quad$ Malinska & 103 & 113 & 142 & 173 & 204 & 222 & 215,5 \\
Omišalj & 1402 & 1541 & 1686 & 1816 & 1860 & 1803 & 128,6 \\
$\quad$ Omišalj & 1329 & 1460 & 1595 & 1697 & 1747 & 1651 & 124,2 \\
Punat & 1536 & 1687 & 2021 & 2509 & 2804 & 2858 & 186,1 \\
$\quad$ Punat & 1241 & 1363 & 1667 & 2120 & 2372 & 2447 & 197,2 \\
Vrbnik & 1868 & 2054 & 2377 & 2593 & 2883 & 2940 & 157,4 \\
$\quad$ Vrbnik & 1241 & 1364 & 1545 & 1639 & 1774 & 1821 & 146,7 \\
Otok Krk & 15237 & 16725 & 18089 & 19871 & 21140 & 21259 & 139,5 \\
\hline
\end{tabular}

Izvor: Smoljanović i sur. (2008), Stanovništvo hrvatskih otoka 2001.

(1) TABLICA 2

Broj stanovnika i indeks promjene broja stanovnika grado va/općina otoka Krka i niihovih sjedišta za 1857 - 1910.
Dok je između 1857. i 1910. samo 9 naselja na otoku imalo ukupnu depopulaciju, u ovom je razdoblju (1910. - 1971.) njih čak 59 bilježilo isti trend. U popisu stanovništva iz 1971. godine naselje Maršići ostalo je bez ijednoga stanovnika. U ovom su se intervalu zbila dva svjetska rata, što je izazvalo velike demografske gubitke, a depopulacija se nastavila i u sljedećim međupopisnim razdobljima. Emigracija postaje glavni uzrok i popratna komponenta konstantno negativnoga populacijskog trenda od 1910. do 1971. na Krku i na cijelom otočnom prostoru. Sve izrazitiji demografski deficit ne može se nadoknaditi prirodnim priraštajem, koji opada (Novosel, 1975). Od 1948. do 1971. stanovništvo otoka Krka smanjeno je za $25,9 \%$, što je ponajviše uzrokovano iseljavanjem u Rijeku. O privlačnoj snazi Rijeke i njezinu utjecaju na stanovništvo Krka svjedoče, između ostaloga, i promjene u težištu naseljenosti te promjene $u$ elipsi stanovništva (naseljenosti), koje su kasnije u ovom radu objašnjene. Osim toga, od 1948. do 1971. stanovništvo Rijeke (naselje) povećalo se sa 66998 na 129173 (indeks promjene 192,8). Sezdesetih godina 20. stoljeća doseljavanje je porastu Grada Rijeke pridonijelo sa 70,7\% (Klempić Bogadi i Podgorelec, 2009). Mogućnost zaposlenja u Rijeci privukla je velik broj doseljenika iz okolice, ali i iz udaljenijih područja Hrvatske i bivše Jugoslavije (Klempić Bogadi, 2008). Smanjenje stanovništva Krka uzrokovalo je višestruko negativne posljedice, koje imaju demografske i agrarno-geografske reperkusije. Između dva svjetska rata poluprazna naselja, socijalni ugar i demografska starost predstavljali su osnovno demografsko obilježje otoka Krka (Novosel-Žic, 1987). 


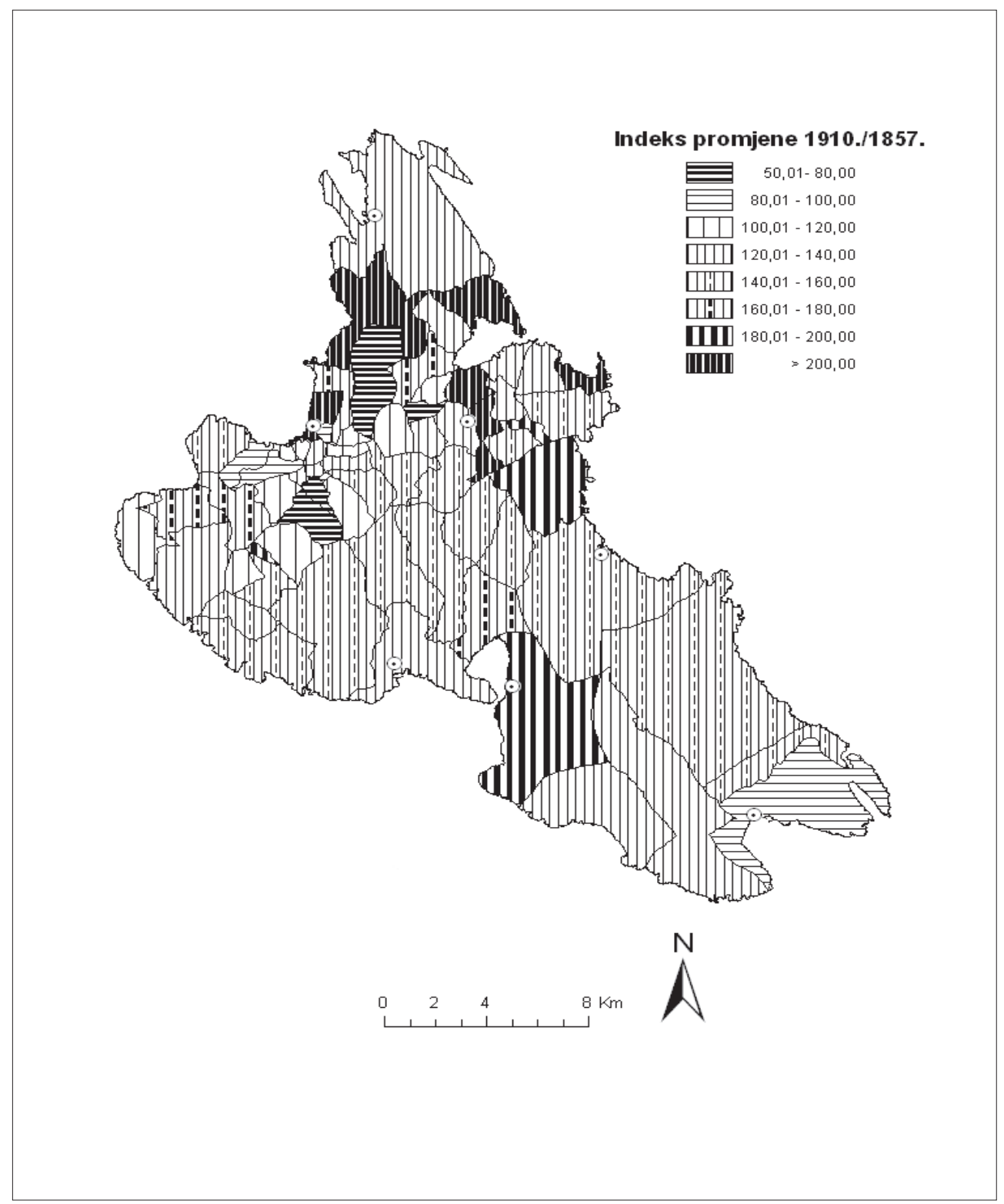

(1) SLIKA 3

Indeks promiene broja stanovnika za 1857. - 1910
3) Između 1971. i 2011. svakim je popisom zabilježen rast broja stanovnika (Tablica 4 i Slika 5). Prema popisu iz 2011. godine, na otoku je živjelo 19383 stanovnika, što je zadnji put zabilježeno potkraj 19. stoljeća. U ovom razdoblju od 40 godinu stanovništvo otoka Krka povećalo se za 6273 stanovnika ili za 47,8\%, tj. prosječno za 157 stanovnika na godinu. Najosjetniji rast bilježi se u općini Omišalj, koja je u vremenu od 40 godina utrostručila broj stanovnika (sa 976 na 2983), te u općini Malinska-Dubašnica koja je $\mathrm{u}$ istom vremenu udvostručila broj stanovnika (sa 1502 na 3134). 


\begin{tabular}{lrrrrrrrr}
\hline Grad/Općina & & & & & & & & \\
Općinsko sjedište & 1910. & 1921. & 1931. & 1948. & 1953. & 1961. & 1971. & $1971 . / 1910$. \\
\hline Baška & 3305 & 3292 & 3172 & 2350 & 2151 & 1797 & 1568 & 47,4 \\
Baška & 1685 & 1550 & 1596 & 1117 & 1016 & 857 & 825 & 49,0 \\
Dobrinj & 4046 & 4036 & 3645 & 3319 & 3112 & 2657 & 2244 & 55,5 \\
Dobrinj & 464 & 453 & 390 & 356 & 323 & 286 & 215 & 46,3 \\
Krk & 4173 & 3937 & 4184 & 4104 & 4045 & 3633 & 3586 & 85,9 \\
Krk & 1778 & 1411 & 1812 & 1473 & 1470 & 1280 & 1531 & 86,1 \\
Malinska-Dubašnica & 2134 & 2003 & 1981 & 1807 & 1755 & 1589 & 1502 & 70,4 \\
Malinska & 222 & 248 & 315 & 290 & 319 & 326 & 392 & 176,6 \\
Omišalj & 1803 & 1670 & 1555 & 1270 & 1170 & 949 & 976 & 54,1 \\
$\quad$ Omišalj & 1651 & 1529 & 1414 & 1095 & 1017 & 791 & 765 & 46,3 \\
Punat & 2858 & 2995 & 2697 & 2305 & 2228 & 1882 & 1551 & 54,3 \\
$\quad$ Punat & 2447 & 2626 & 2320 & 1958 & 1917 & 1635 & 1390 & 56,8 \\
Vrbnik & 2940 & 2909 & 2809 & 2534 & 2359 & 2041 & 1683 & 57,2 \\
$\quad$ Vrbnik & 1821 & 1791 & 1748 & 1532 & 1408 & 1254 & 1052 & 57,8 \\
& & & & & & & & \\
Otok Krk & 21259 & 20842 & 20043 & 17689 & 16820 & 14548 & 13110 & 61,7 \\
\hline
\end{tabular}

Izvor: Smoljanović i sur. (2008), Stanovništvo hrvatskih otoka 2001.

(1) TABLICA 3

Broj stanovnika i indeks promjene gradova/općina i niihovih sjedišta za 1910. - 1971.

(1) TABLICA 4

Broj stanovnika i indeks promiene gradova/općina i niihovih sjedišta za 1971. - 2011.
U ovom razdoblju jedino općine Dobrinj i Vrbnik bilježe pad broja stanovnika. U općini Dobrinj broj stanovnika smanjio se za 166 ili 7,4\%, dok je u općini Vrbnik smanjenje iznosilo 423 stanovnika ili 23,1\%. Od općinskih sjedišta, u ovom razdoblju pad stanovništva imala su samo naselje Dobrinj (za $49,3 \%$ ) i naselje Vrbnik (za 9,9\%). Dakle, dok općine i njihova sjedišta na sjeveroistoku otoka bilježe pad broja stanovnika, ostale ga općine (višestruko) povećavaju.

\begin{tabular}{lrrrrrrr}
\hline Grad/Općina & & & & & & & \\
Općinsko sjedište & 1971. & 1981. & 1991. & 2001. & 2011. & $2011 . / 1971$. & $2011 . / 2001$. \\
\hline Baška & 1568 & 1439 & 1456 & 1554 & 1674 & 106,8 & 107,7 \\
Baška & 825 & 776 & 816 & 901 & 981 & 118,9 & 108,9 \\
Dobrinj & 2244 & 1949 & 1944 & 1970 & 2078 & 92,6 & 105,5 \\
Dobrinj & 215 & 159 & 122 & 122 & 109 & 50,7 & 89,3 \\
Krk & 3586 & 3918 & 4997 & 5491 & 6281 & 175,1 & 114,4 \\
Krk & 1531 & 2077 & 3022 & 3364 & 3730 & 243,6 & 110,9 \\
Malinska-Dubašnica & 1502 & 1752 & 2161 & 2726 & 3134 & 208,7 & 115,0 \\
Malinska & 392 & 700 & 999 & 607 & 965 & 246,2 & 159,0 \\
Omišalj & 976 & 1235 & 2723 & 2998 & 2983 & 305,6 & 99,5 \\
Omišalj & 765 & 914 & 1554 & 1790 & 1868 & 244,2 & 104,4 \\
Punat & 1551 & 1645 & 1808 & 1876 & 1973 & 127,2 & 105,2 \\
Punat & 1390 & 1546 & 1696 & 1784 & 1860 & 133,8 & 104,3 \\
Vrbnik & 1683 & 1396 & 1313 & 1245 & 1260 & 76,9 & 101,2 \\
Vrbnik & 1052 & 938 & 950 & 944 & 948 & 90,1 & 100,4 \\
Otok Krk & 13110 & 13334 & 16402 & 17860 & 19383 & 147,8 & 108,5 \\
\hline
\end{tabular}

Izvor: Smoljanović i sur. (2008), Stanovništvo hrvatskih otoka 2001., Popis stanovništva, kućanstava i stanova 2011. (http://www.dzs.hr). 


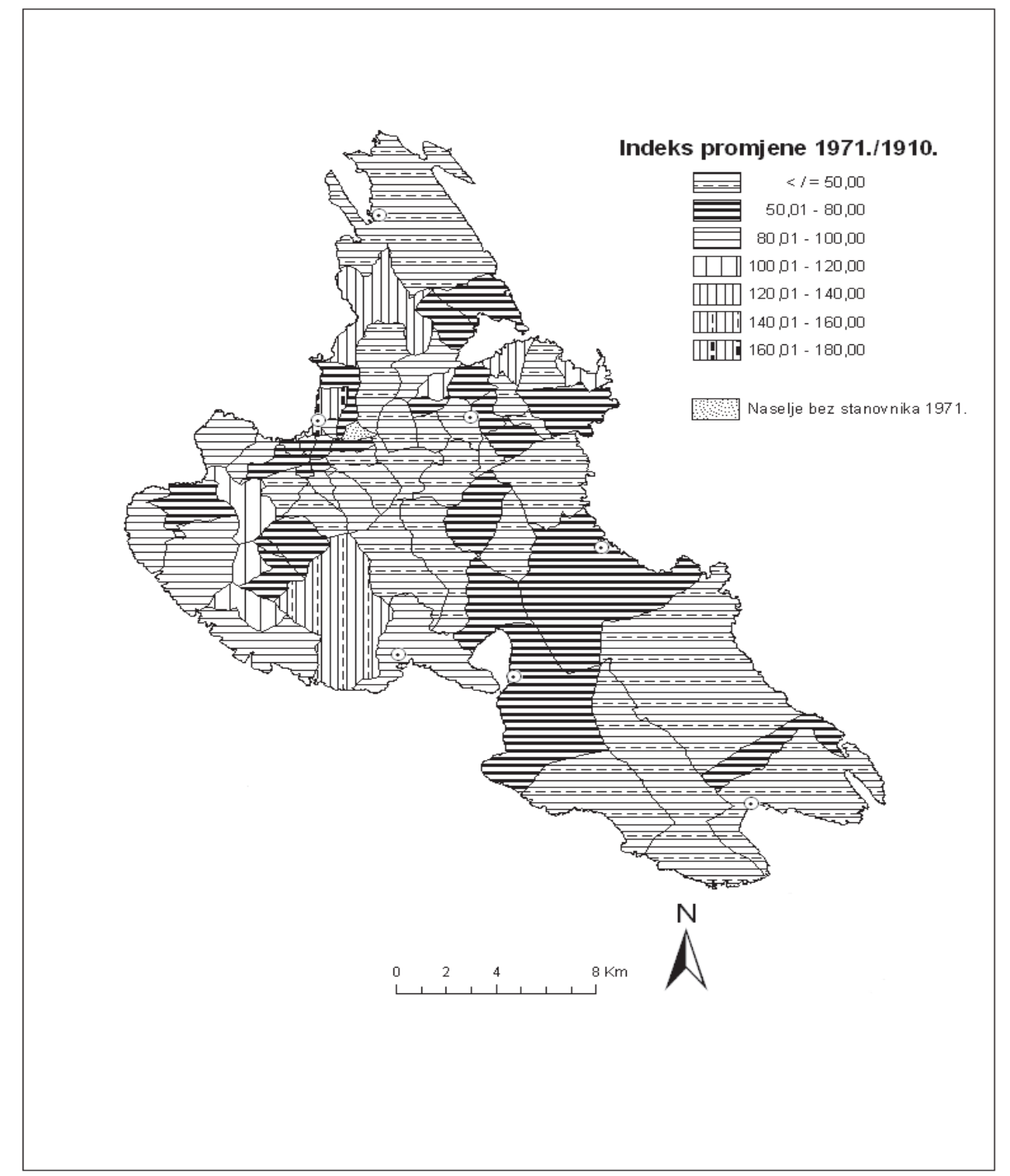

i) SLIKA 4

Indeks promiene ukup noga broja stanovnika za 1910. - 1971.
Razlozi rasta broja stanovnika višestruki su. Naime, sedamdesetih godina dolazi do bržeg razvoja turizma, za koji otočni prostor pruža nove razvojne mogućnosti. Dolazi do preorijentacije gospodarske strukture dijela otočnoga prostora prema turizmu i djelatnostima vezanim uz njega, što je zajednički pridonijelo njegovoj atraktivnosti, razvoju i općenito naznačilo put moguće revitalizacije. Snažan turistički i vikendaški razvoj otok Krk može zahvaliti blizini važnih domaćih i inozemnih emitivnih područja, odnosno povoljnom promet- 
DRUŠ. ISTRAŽ. ZAGREB GOD. 22 (2013), BR. 1 STR. 167-193

JOVANIĆ, M., TURK, I.: PROMJENE U... nom i turističko-geografskom položaju (H. Turk, 1994). Takav je razvoj usporio iseljavanje, čime je smanjena i depopulacija. Na dijelu otočnoga prostora Hrvatske useljavanje je nadraslo iseljavanje, pa je zabilježen porast broja stanovnika (Vojnović, 1993).

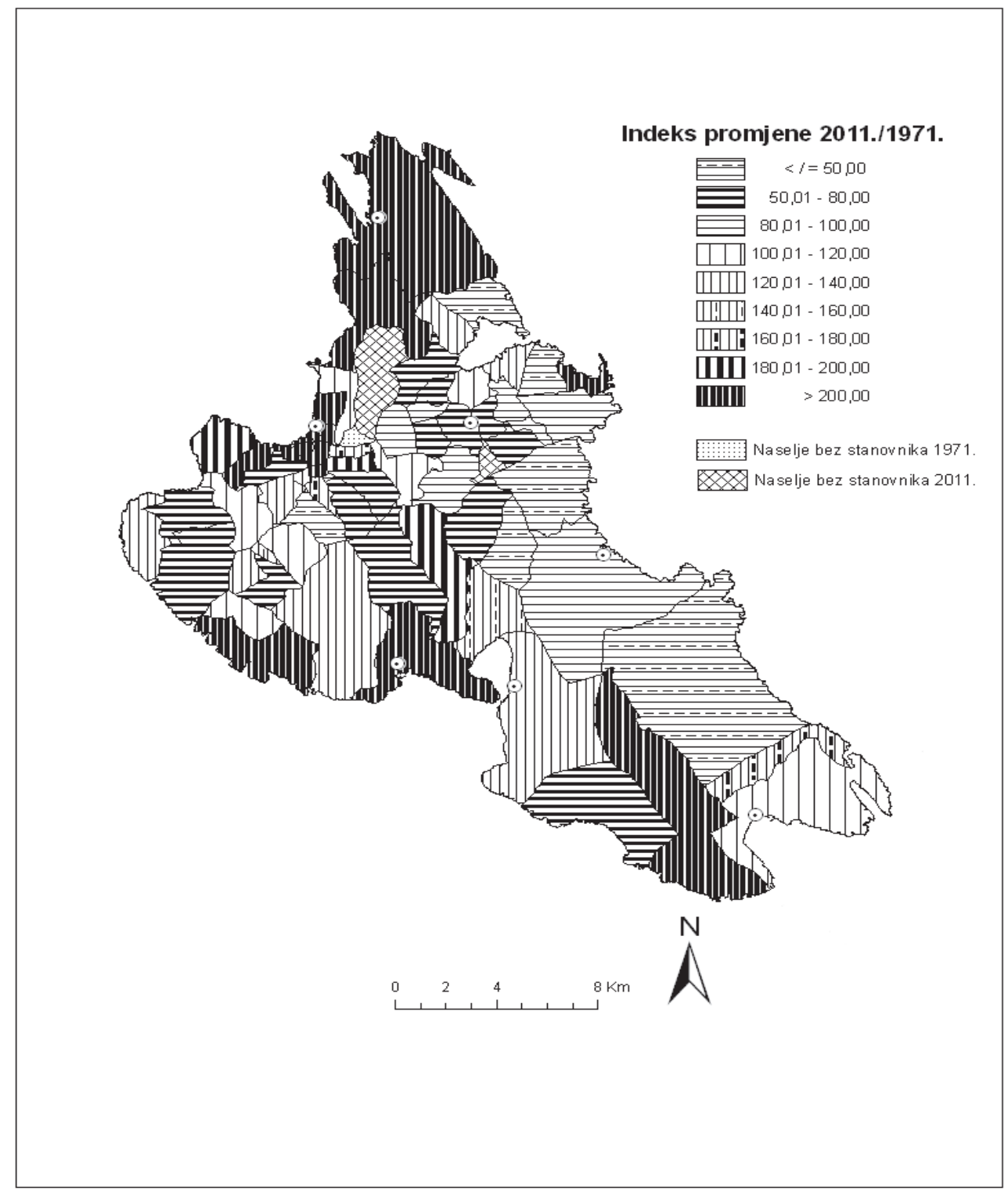

i SLIKA 5

Indeks promiene ukupnoga broja stanovnika za 1971. - 2011.
Uz turizam, sedamdesetih je godina na otoku Krku omogućen razvoj još jedne gospodarske grane - izgrađen je petrokemijski kompleks te tankerski i naftovodni terminal u blizini Omišlja, što je uz izgradnju Krčkoga mosta 1980. godine privuklo doseljavanje novoga stanovništva. Istodobno s dru- 
(1) SLIKA 6

Indeks promiene ukupnoga broja stanovnika od 2001 do 2011. štveno-ekonomskim napretkom dolazi do promjena u prostornoj pokretljivosti - slabi intezitet doseljavanja u Rijeku, a jača dnevna cirkulacija, što pridonosi razvoju naseljenosti riječke gradske regije. Sve navedeno uvjetuje uzastopan porast ukupnoga broja stanovnika otoka Krka od sedamdesetih godina 20. stoljeća do danas.

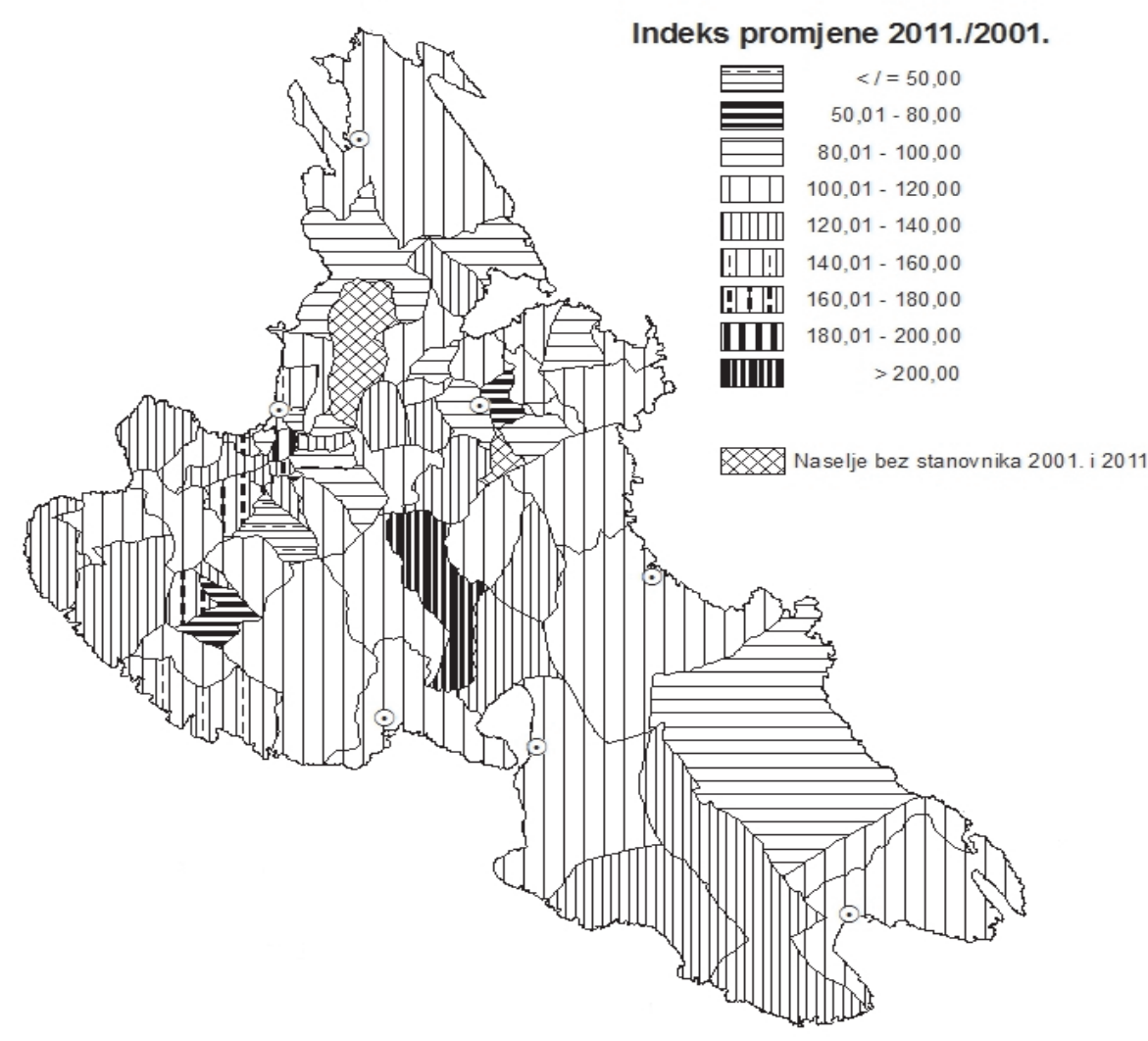

U najnovijem su međupopisju (2001. - 2011.) svi gradovi/općine na Krku, osim općine Omišalj, zabilježile blagi ili umjereni porast broja stanovnika. Općina Omišalj zabilježila je neznatan pad broja stanovnika (indeks promjene 99,5). Na- 
DRUŠ. ISTRAŽ. ZAGREB GOD. 22 (2013), BR. 1 STR. 167-193

JOVANIĆ, M., TURK, I.: PROMJENE U... suprot tome, naselje Omišalj zabilježilo je porast broja stanovnika (indeks promjene 104,4). Sva su središnja naselja gradova/općina, osim Dobrinja, zabilježila porast broja stanovnika. Pad broja stanovnika naselja Dobrinj uvjetovan je njegovim položajem u unutrašnjosti otoka.

Diferencijaciju kretanja broja stanovnika na razini gradova/općina s obzirom na njihov prostorni smještaj od druge polovice 19. stoljeća potvrđuje sljedeće: u općinama istočne, odnosno jugoistočne, strane otoka (općine Baška, Dobrinj, Punat i Vrbnik) broj stanovnika 2011. godine bio je tek polovica njihovih maksimuma. Najveći broj stanovnika bilježi općina Baška 1900. godine, u općinama Dobrinj i Vrbnik 1910., a u općini Punat 1921. S druge strane, Grad Krk te općine Malinska-Dubašnica i Omišalj na zapadnoj, odnosno sjevernoj, strani otoka upravo prema najnovijem popisu (2011.) bilježe najveći broj stanovnika. Iako su na početku 20. stoljeća (Omišalj 1900. godine, Malinska-Dubašnica 1910., Krk 1931.) imale sekundarni maksimum nakon kojega je uslijedio lagani pad broja stanovnika, uzastopni porast broja stanovnika bilježe od sedamdesetih (Omišalj), odnosno osamdesetih, godina 20. stoljeća (Krk, Malinska-Dubašnica). Razloge ovakve dvojnosti u kretanju broja stanovnika možemo naći u razvoju industrije, intenzivnijem razvoju turizma i boljoj prometnoj povezanosti Grada Krka te spomenutih općina s kopnom. Ovakva razlika u kretanju broja stanovnika ogleda se i u premještanju težišta naseljenosti prema sjeverozapadu, odnosno premještanje elipse naseljenosti prema sjeveru.

Uspješan turistički oporavak u zadnjih desetak godina bio je praćen nastavkom vikendaške izgradnje na Krku. Zbog ratnih okolnosti u Hrvatskoj jačanje vikendaštva odvijalo se nešto usporenije u prvoj polovici 1990-ih, no smirivanjem ratnih prilika ono je doživjelo nagli uzlet, koji se nastavio i na početku 2000-ih. Kao i u ranijim razdobljima, povećanju broja vikendica na Krku u suvremenom razdoblju pogodovalo je povećanje njegove prostorne dostupnosti (Opačić, 2008).

Naposljetku se može zaključiti kako su na kretanje broja stanovnika otoka Krka u promatranom razdoblju od 1857. do 2011. utjecali: 1) emigracija stanovništva uzrokovana propadanjem vinogradarstva i pomorstva, 2) efekti jake prekomorske emigracije, 3) izravni i neizravni demografski gubici povezani sa svjetskim ratovima, 4) efekti preseljavanja u urbane centre, posebice Rijeku, 5) naslijeđena populacijsko-naseljska struktura, 6) imigracija stanovništva uvjetovana razvojem turizma i 7) imigracija stanovništva izazvana suburbanizacijom Rijeke, koja se ogleda i u izgradnji riječke zračne luke i naftnoga terminala sedamdesetih godina te Krčkoga mosta 1980. godine. 


\section{VELIČINA NASELJA}

\begin{tabular}{|c|c|c|c|c|c|c|c|c|}
\hline \multirow[b]{2}{*}{ Godina } & \multicolumn{8}{|c|}{ Veličina naselja (broj stanovnika) } \\
\hline & $\begin{array}{r}1 \\
-50\end{array}$ & $\begin{array}{r}51 \\
-100\end{array}$ & $\begin{array}{r}101 \\
-200\end{array}$ & $\begin{array}{r}201 \\
-500\end{array}$ & $\begin{array}{r}501 \\
-1000\end{array}$ & $\begin{array}{r}1001 \\
-2000\end{array}$ & $>2000$ & $\begin{array}{l}\text { Naselje bez } \\
\text { stanovnika }\end{array}$ \\
\hline 1857. & 15 & 22 & 13 & 12 & 1 & 5 & - & - \\
\hline 1869. & 12 & 24 & 14 & 12 & 1 & 5 & - & - \\
\hline 1880. & 10 & 24 & 14 & 13 & 2 & 4 & 1 & - \\
\hline 1890. & 8 & 20 & 20 & 13 & 2 & 3 & 2 & - \\
\hline 1900. & 6 & 21 & 19 & 12 & 4 & 4 & 2 & - \\
\hline 1910. & 10 & 17 & 19 & 13 & 3 & 5 & 1 & - \\
\hline 1921. & 12 & 14 & 21 & 12 & 3 & 5 & 1 & - \\
\hline 1931. & 14 & 14 & 19 & 12 & 3 & 5 & 1 & - \\
\hline 1948. & 14 & 11 & 20 & 15 & 3 & 5 & - & - \\
\hline 1953. & 15 & 14 & 19 & 12 & 3 & 5 & - & - \\
\hline 1961. & 18 & 14 & 17 & 12 & 4 & 3 & - & - \\
\hline 1971. & 19 & 17 & 15 & 9 & 4 & 3 & - & 1 \\
\hline 1981. & 22 & 17 & 13 & 7 & 5 & 1 & 1 & 2 \\
\hline 1991. & 20 & 18 & 12 & 7 & 4 & 3 & 1 & 3 \\
\hline 2001. & 16 & 17 & 17 & 7 & 5 & 3 & 1 & 2 \\
\hline 2011. & 16 & 12 & 19 & 11 & 4 & 3 & 1 & 2 \\
\hline
\end{tabular}

Izvor: Smoljanović i sur. (2008), Stanovništvo hrvatskih otoka 2001., Popis stanovništva, kućanstava i stanova 2011. (http://www.dzs.hr).

\begin{tabular}{lrrrrr}
\hline & \multicolumn{2}{r}{ Naselja } & & \multicolumn{2}{c}{ Stanovništvo } \\
\cline { 2 - 4 } Veličina naselja (broj stanovnika) & $\begin{array}{r}\text { Broj } \\
\text { naselja }\end{array}$ & $\%$ & & $\begin{array}{c}\text { Broj } \\
\text { stanovnika }\end{array}$ & $\%$ \\
\hline $1-50$ & 16 & 23,5 & & 389 & 2,0 \\
$51-100$ & 12 & 17,7 & & 850 & 4,4 \\
$101-200$ & 19 & 27,9 & & 2697 & 13,9 \\
$201-500$ & 11 & 16,2 & & 3134 & 16,2 \\
$501-1000$ & 4 & 5,9 & & 3740 & 19,3 \\
$1001-2000$ & 3 & 4,4 & & 4843 & 25,0 \\
$>2000$ & 1 & 1,5 & 3730 & 19,2 \\
Naselje bez stanovnika & 2 & 2,9 & & - & - \\
Otok Krk & 68 & 100,0 & 19383 & 100,0 \\
\hline
\end{tabular}

Izvor: Popis stanovništva, kućanstava i stanova 2011. (http://www.dzs.hr).

Dn TABLICA 5 Broi naselja prema veličini od 1857 do 2011 . godine

i TABLICA 6 Struktura naselja po veličini 2011 . godine
Najveće naselje (3730 stanovnika ili 19,2\% stanovništva otoka) na otoku jest grad Krk, koji je ujedno jedino gradsko naselje na otoku. Slijede naselja Omišalj (1868), Punat (1860) i Njivice (1115). To su ujedno sva naselja sa više od 1000 stanovnika. Zanimljivo je da oba naselja u općini Omišalj (Omišalj i Njivice) imaju više od 1000 stanovnika, dok ni jedno od 20 na- 
DRUŠ. ISTRAŽ. ZAGREB GOD. 22 (2013), BR. 1, STR. 167-193

JOVANIĆ, M., TURK, I.: PROMJENE U.. selja općine Dobrinj nema više od 400 stanovnika (najveće Šilo broji 384 stanovnika). Četiri najveća naselja na otoku (jedina koja broje više od 1000 stanovnika - Krk, Omišalj, Punat, Njivice) okupljaju čak 8573 stanovnika ili 44,2\% stanovništva otoka. Sva su se veća naselja razvila na obali i povezana su državnom cestom.

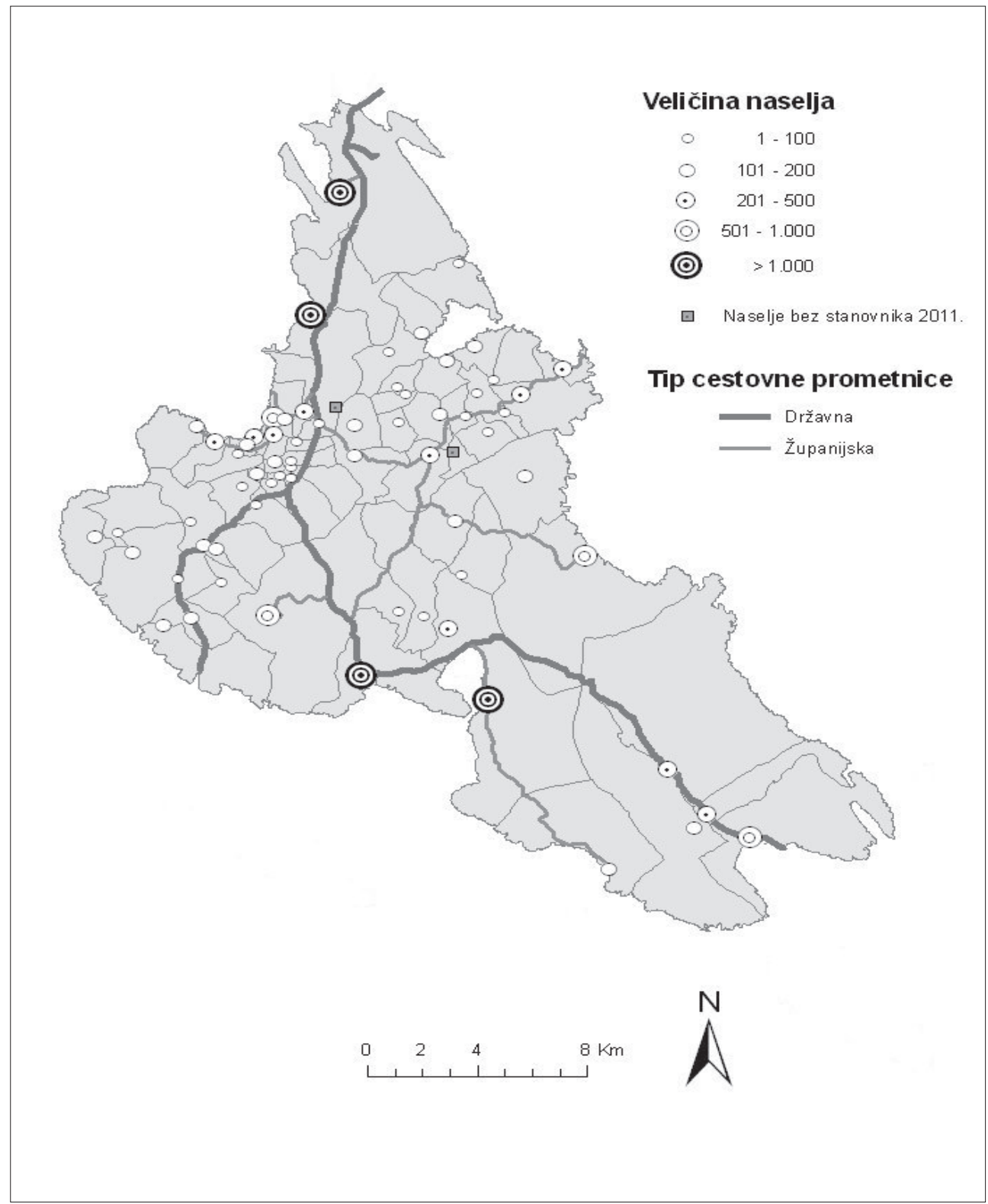

(1) SLIKA 7

Veličina naselja otoka

Krka 2011. godine 


\section{DIFERENCIRANI DEMOGRAFSKI RAZVOJ OBALNIH NASELJA I NASELJA U UNUTRAŠNJOSTI}

Položaj uz more velika je prednost obalnih naselja, jer more pruža (turističke) mogućnosti i perspektive. Od 68 naselja otoka Krka, na obalama se razvilo 15 naselja,7 koja su tijekom prošlosti - ovisno o veličini i broju stanovnika - različito iskorištavala svoj maritimni položaj. Bez obzira na veličinu, sva obalna naselja danas su orijentirana na more, odnosno na razvoj turizma. Stoga se prirodno i društveno-gospodarski raznolike obale i čitav prostor otoka Krka danas objedinjuje pod utjecajem turizma (Novosel-Žic, 1987). Suvremeno doba donosi velike promjene $u$ unutrašnjim naseljima otoka, koja se sve više orijentiraju prema obali, ${ }^{8}$ pa se prostorno i funkcionalno uključuju u nove procese. Prostorni učinak turizma ograničen je i utjecaj mu se smanjuje udaljavanjem od obale (Nejašmić, 1999). Naselja u unutrašnjosti otoka posredno osjećaju impulse turizma, jer oblici turizma koji nisu orijentirani na more na otoku još nisu dovoljno razvijeni. Od 1971. do 2011.

(1) TABLICA 7

Apsolutni broj i relativni udio stanovništva naselja otoka Krka s obzirom na udalienost od obale došlo je do povećanja apsolutnoga broja i relativnog udjela stanovništva obalnih naselja. U tom razdoblju stanovništvo obalnih naselja povećalo se za 5808 stanovnika ili 81,0\%, dok kod naselja u unutrašnjosti to je povećanje bilo tek za 465 stanovnika ili 7,8\%, što govori o intenzitetu litoralizacije na otoku.

\begin{tabular}{|c|c|c|c|c|c|c|c|c|c|c|}
\hline \multirow{3}{*}{$\begin{array}{l}\text { Naseljska skupina } \\
\text { (položaj) }\end{array}$} & \multirow{2}{*}{\multicolumn{2}{|c|}{1971.}} & \multicolumn{8}{|c|}{ Godina } \\
\hline & & & & 1981. & & 1991. & & 2001. & & 2011. \\
\hline & Aps. & $\%$ & Aps. & $\%$ & Aps. & $\%$ & Aps. & $\%$ & Aps. & $\%$ \\
\hline Naselja na obali & 7167 & 54,7 & 8223 & 61,7 & 11278 & 68,8 & 11852 & 66,4 & 12975 & 66,9 \\
\hline Naselja u unutrašnjosti & 5943 & 45,3 & 5111 & 38,3 & 5124 & 31,2 & 6008 & 33,6 & 6408 & 33,1 \\
\hline Otok Krk & 13110 & 100,0 & 13334 & 100,0 & 16402 & 100,0 & 17860 & 100,0 & 19383 & 100,0 \\
\hline
\end{tabular}

Izvor: Smoljanović i sur. (2008), Stanovništvo hrvatskih otoka 2001., Popis stanovništva, kućanstava i stanova 2011. (http://www.dzs.hr).

\section{TEŽIŠTE NASELJENOSTI}

Određivanje težišta naseljenosti primjenom GIS-a za pojedine popisne godine i njihovo uspoređivanje odličan je način za uočavanje i matematičko-statističko sažimanje trenda promjene naseljenosti (Valožić, 2007). Na slici 6 može se vidjeti kako 16 ucrtanih lokacija iščitavaju pomake prosječnoga centra naseljenosti otoka Krka za svaku od promatranih popisnih godina. Vidljivo je kako je taj pomak od sredine 19. stoljeća usmjeren prema sjeverozapadu, što je u skladu s jačim razvojem turizma zapadne (blaže položene) obale te rastom broja stanovnika u naseljima sjevernoga dijela otoka, što je uvjetovano izgradnjom riječke zračne luke, naftnoga kompleksa u Omišlju i Krčkoga mosta koji otok spaja s kopnom. 


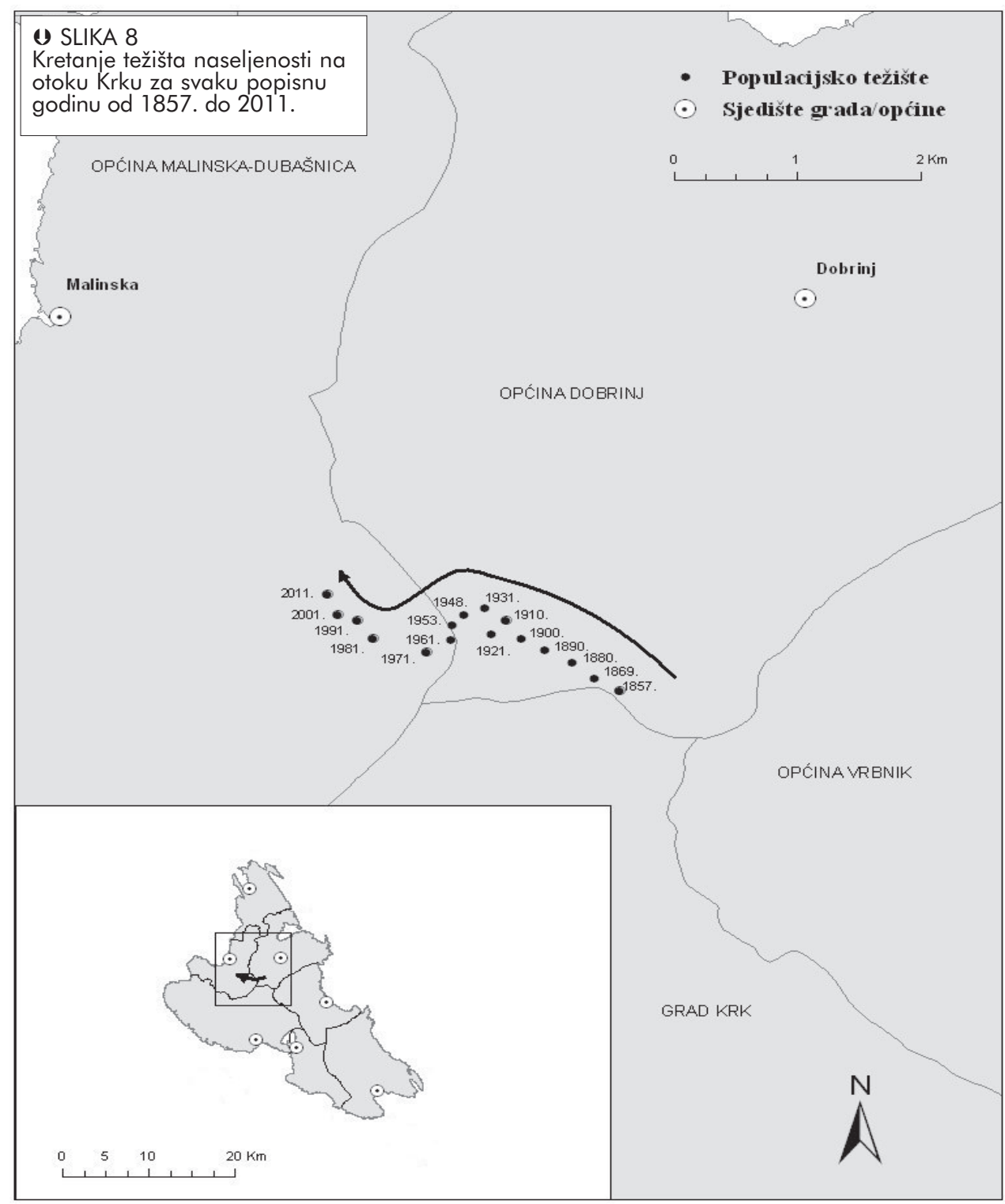

\section{ELIPSA STANOVNIŠTVA}

Elipsa stanovništva vrlo je dobra metoda za utvrđivanje i prikazivanje trenda usmjerenosti razmještaja naselja na otoku Krku (Jovanić, 2011). U ovom radu uzete su u obzir dvije varijante ove metode: trend usmjerenosti s obzirom na prostorni razmještaj naselja i trend usmjerenosti s obzirom na prostorni razmještaj i broj stanovnika pojedinoga naselja za godine 1857 . i 2011. Kao što i sam naziv kaže, rezultat ove metode jesu elipse različita smjera, oblika i položaja. Naselja su uglavnom smje- 
štena u središnjem dijelu otoka, što pokazuje smještaj i oblik elipse prostornog razmještaja naselja.

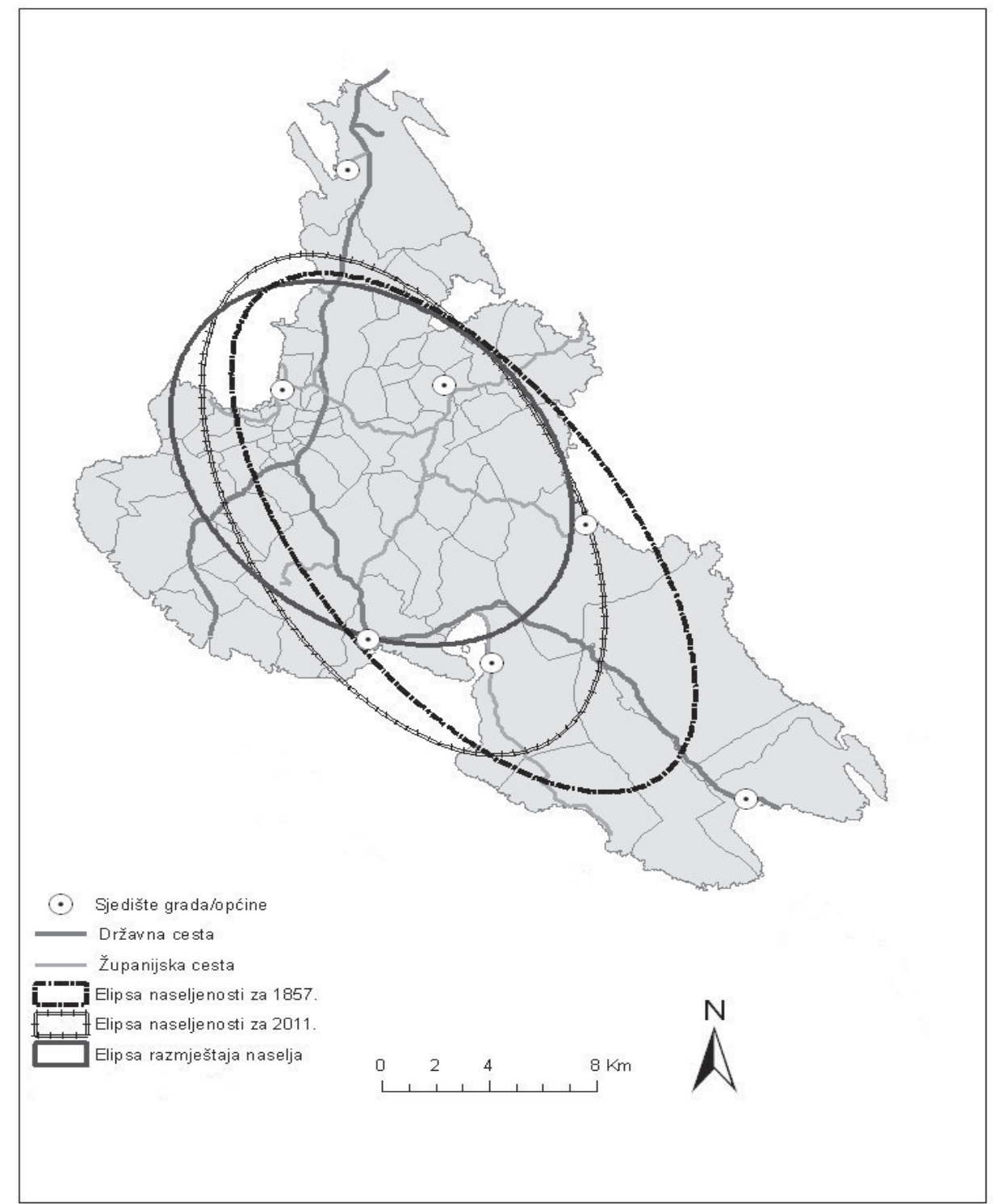

i SLIKA 9

Elipsa razmještaja naselia i elipse naselienosti otoka Krka za 1857. i 2011 . godinu
Izduženiji oblik elipsa za naseljenost 1857. i 2011. od elipse prostornog rasporeda naselja upućuje na svojevrsnu polariziranost rasporeda naselja s velikim brojem stanovnika (Omišalj i Njivice na sjevernom te Krk, Punat i Baška na južnom dijelu otoka), dok se velik broj malih naselja nalazi u srednjem dijelu otoka Krka. Sjeverozapadniji položaj i manji ekscentricitet elipse naseljenosti iz 2011., od onog iz 1857., u skladu je s premještanjem težišta naseljenosti otoka. Jasno je da je pre- 
mještaj težišta naseljenosti otoka Krka usko povezan s jačanjem gravitacijskog utjecaja Rijeke, što je posebice izraženo nakon izgradnje Krčkoga mosta.

\section{PRIRODNO KRETANJE STANOVNIŠTVA}

Otok Krk još od ranih 60-ih godina bilježi prirodan pad stanovništva. U promatranom razdoblju (1964. - 2011.) samo je u 4 godine zabilježena pozitivna prirodna promjena: 1977. (0,8\%o), 1984. $(1,0 \%)$, 1987. $(0,9 \%$ i i 1988. (1,0\%o). Najveće stope pada zabilježene su 1967. $(-8,3 \%$ i i 1999. $(-7,2 \%$ o $)$.

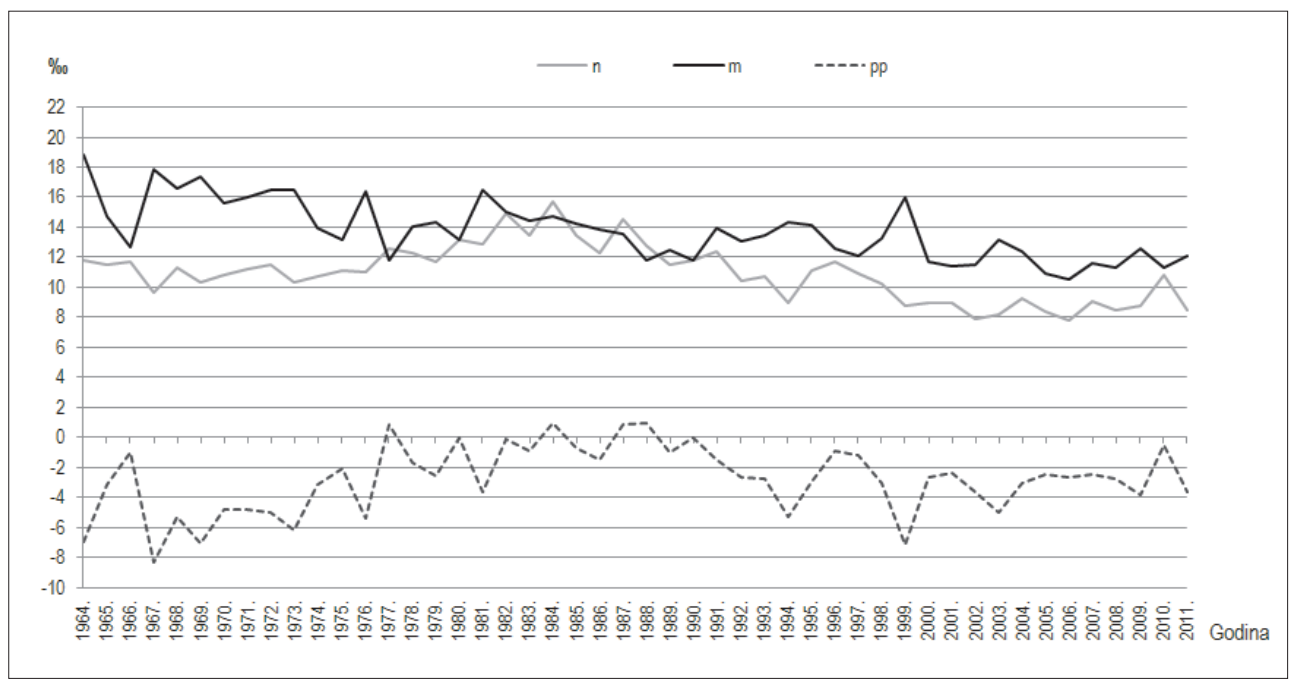

Izvor: Vitalna statistika za pojedine godine 1964. - 2011., DZS RH.

(1) SLIKA 10

Stope rodnosti $(n)$, smrtnosti $(\mathrm{m}) \mathrm{i}$

prirodne promiene (pp) otoka Krka od 1964. do 2011.
Prirodni pad stanovništva ponajprije je rezultat izrazito visokih stopa mortaliteta (prosječna stopa mortaliteta od 1964. do 2011. iznosila je 13,8\%o). Ovako visoke stope mortaliteta odraz su visokog udjela staroga stanovništva, jer je dugotrajnim iseljavanjem mlađega stanovništva ukupna populacija ostarjela, oslabljena je demoreprodukcija, pa je negativno prirodno kretanje logična posljedica spomenutih procesa. Prosječna stopa nataliteta u ovom razdoblju iznosila je 11,0\%o, a prosječna prirodna promjena stanovništva $-2,9 \%$. Vidi se da je od 2001. do 2011. prirodna promjena negativnoga predznaka u svim jedinicama lokalne samouprave, osim u općini Omišalj. Dakle, otok Krk je u promatranom međupopisnom razdoblju prirodnom depopulacijom izgubio 597 stanovnika. Na temelju vitalnog indeksa ${ }^{9}$ na razini grada/općine možemo zaključiti kako je jedino u općini Omišalj u promatranom razdoblju (2001. - 2011.) bilo više živorođenih nego umrlih osoba (vitalni indeks veći je od 100 i iznosio je 116,67). 


\begin{tabular}{|c|c|c|c|c|c|c|c|}
\hline $\begin{array}{l}\text { Grad/ } \\
\text { Općina }\end{array}$ & $\begin{array}{r}\text { Broj } \\
\text { ođenih } \\
(\mathrm{N})\end{array}$ & $\begin{array}{r}\text { Broj } \\
\text { umrlih } \\
(\mathrm{M})\end{array}$ & $\begin{array}{r}\text { Prirodna } \\
\text { promjena } \\
\left(\mathrm{P}_{\mathrm{P}}\right)\end{array}$ & $\begin{array}{r}\text { Opća stopa } \\
\text { rodnosti } \\
\text { (prosječna } \\
\text { godišnja } \\
\text { 2001.-2011.) }\end{array}$ & $\begin{array}{r}\text { Opća stopa } \\
\text { smrtnosti } \\
\text { (prosječna } \\
\text { godišnja } \\
\text { 2001.-2011.) }\end{array}$ & $\begin{array}{r}\text { Stopa } \\
\text { prirodne } \\
\text { promjene } \\
\text { (prosječna } \\
\text { godišnja } \\
\text { 2001.-2011.) }\end{array}$ & $\begin{array}{r}\text { Vitalni } \\
\text { indeks } \\
\left(\mathrm{V}_{\mathrm{i}}\right)\end{array}$ \\
\hline Baška & 141 & 277 & -136 & 7,95 & 15,57 & $-7,62$ & 50,90 \\
\hline Dobrinj & 162 & 355 & -193 & 7,37 & 16,17 & $-8,80$ & 45,63 \\
\hline Krk & 625 & 703 & -78 & 9,63 & 10,87 & $-1,24$ & 88,90 \\
\hline Malinska-Dubašnica & 311 & 350 & -39 & 9,60 & 10,80 & $-1,21$ & 88,86 \\
\hline Omišalj & 273 & 234 & 39 & 8,30 & 7,11 & 1,19 & 116,67 \\
\hline Punat & 165 & 268 & -103 & 7,82 & 12,71 & $-4,89$ & 61,57 \\
\hline Vrbnik & 130 & 212 & -82 & 9,39 & 15,31 & $-5,92$ & 61,32 \\
\hline Otok Krk & 1807 & 2404 & -597 & 8,80 & 11,69 & $-2,89$ & 75,17 \\
\hline
\end{tabular}

Izvor: Vitalna statistika za pojedine godine 2001. - 2011., DZS Republike Hrvatske.

(1) TABLICA 8

Prirodno kretanje stanovništva i vitalni indeks gradova/općina otoka Krka od 2001. do 2011.
Gotovo sva naselja u kojima je bilo više živorođenih nego umrlih povezana su državnom cestom, što svjedoči o važnosti prometne dostupnosti (Jovanić, 2011). Uzimajući u obzir da je popisno kretanje broja stanovnika na razini cijelog otoka od 1971. godine $u$ porastu, a prirodno kretanje uglavnom je negativnoga predznaka, može se zaključiti da je porast stanovništva uvjetovan imigracijom stanovništva koje slabije sudjeluje $\mathrm{u}$ demoreprodukciji.

\section{MIGRACIJA STANOVNIŠTVA}

Već je napomenuto da je u drugoj polovici 19. stoljeća emigracija otočana bila posljedica nepovoljnih ekonomskih prilika. One su uzrokovane propašću jedrenjačke kabotažne plovidbe, propašću vinograda zbog filoksere, kao i vinskom klauzulom, kojom se poticao uvoz talijanskoga vina u Austro-Ugarsku. Stanovništvo otoka Krka u ovom se razdoblju iseljava $\mathrm{u}$ prekomorske zemlje, Rijeku, istarske gradove (Pula, Poreč) i u ostale urbane centre u unutrašnjosti zemlje. Rijeka se od 19. stoljeća razvija u jak industrijski i pomorski centar, što privlačno djeluje na stanovništvo iz okolice, pa tako i otoka Krka. ${ }^{10}$ Time stanovnici otoka Krka sudjeluju u jakim kretanjima na relaciji selo - grad (Novosel, 1972). Najdinamičnije razdoblje porasta broja stanovnika Rijeke bilo je ono 50-ih i 60-ih godina 20 . stoljeća, u vrijeme intenzivna razvoja lučkih funkcija i industrije. Velik porast broja radnih mjesta bio je najvažniji čimbenik jakoga doseljavanja (Klempić Bogadi, 2008). Od 1948. do 1971. stanovništvo otoka Krka smanjeno je za 25,9\%, što je ponajviše uzrokovano iseljavanjem prema gradu Rijeci. S otoka Krka u početku je odlazila pretežno nekvalificirana, fizička radna snaga iz redova sitnih poljoprivrednika, jer struč- 
DRUŠ. ISTRAŽ. ZAGREB GOD. 22 (2013), BR. 1 STR. 167-193

JOVANIĆ, M., TURK, I.: PROMJENE U...
(1) SLIKA 11

Doseljeni na otok Krk prema miestu prethodnoga boravka za 2001. godinu noga i školovanoga kadra nije bilo mnogo. S vremenom se popravlja obrazovna struktura stanovništva, pa se mlađi ljudi češće zapošljavaju izvan otoka, ponajviše u Rijeci. To je uzrokovalo višestruko negativne posljedice. Između dva svjetska rata poluprazna naselja, socijalni ugar i demografska starost predstavljali su osnovno obilježje otoka (Novosel-Žic, 1987). Od 1971. do 1981. dolazi do smanjenja dinamike porasta gradskoga stanovništva Hrvatske, pa tako i Rijeke, a to se nastavlja i od 1981. do 1991. Nakon razdoblja kontinuiranoga porasta stanovništva, u međupopisnom razdoblju od 1991. do 2001. prvi put nakon Drugoga svjetskog rata Rijeka bilježi pad broja stanovnika (za 11,2\%). Razlozi za to jesu nepovoljno prirodno kretanje i negativna migracijska bilanca. U ovom razdoblju intenzivira se i iseljavanje stanovništva iz centralnih gradova u okolicu kao rezultat jačanja procesa suburbanizacije, što se pozitivno odrazilo na populacijski rast prigradskih naselja (Klempić Bogadi i Podgorelec, 2009). Već je istaknuto da se suburbanizacija Rijeke ogleda i u izgradnji naftnoga terminala i zračne luke na sjevernom dijelu otoka sedamdesetih godina 20 . stoljeća, kao i u izgradnji Krčkoga mosta 1980. godine, što otok Krk još snažnije uključuje u dnevni urbani sistem Rijeke. Osim toga, dolazi do jakog razvoja turizma na otoku i jačanja procesa litoralizacije.

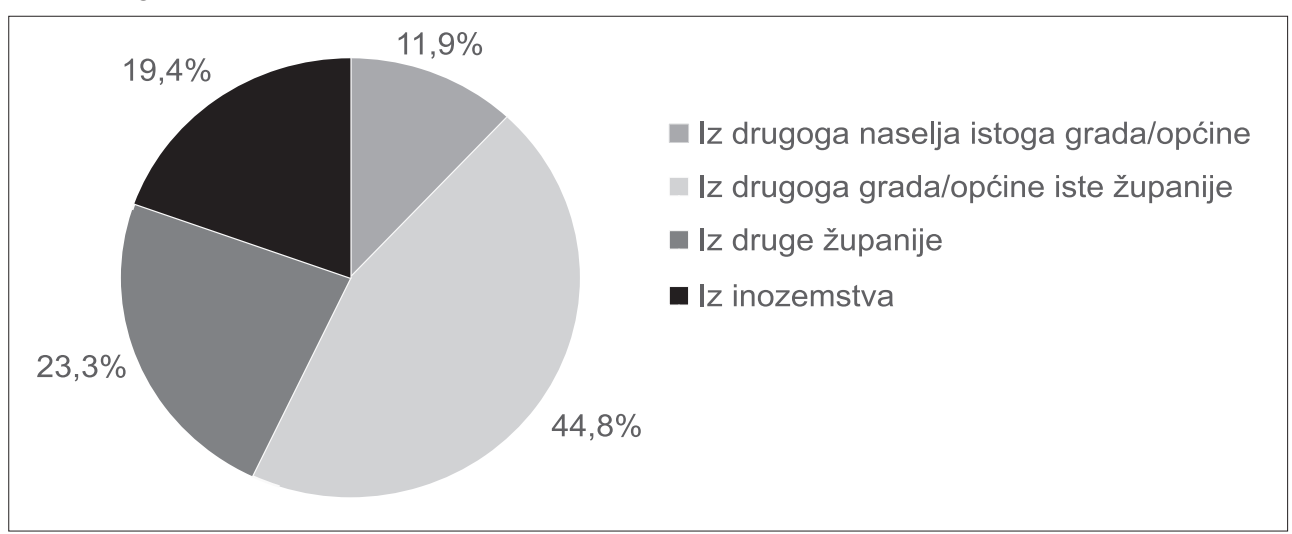

Izvor: Popis stanovništva, kućanstava i stanova 31. ožujka 2001., Stanovništvo prema migracijskim obilježjima, po gradovima/općinama (http://www.dzs.hr).

Od ukupno 17860 stanovnika na otoku Krku 2001. godine, čak je njih 10106 (56,6\%) bilo doseljeno, a 43,4\% bilo je domicilno stanovništvo. Očekivano je najviše doseljenih bilo u općinama na sjevernom dijelu otoka: općina Omišalj $(69,6 \%)$ i općina Malinska-Dubašnica $(64,8 \%)$. Sve jedinice lokalne samouprave, osim općine Vrbnik (33,8\%), imale su više od 50\% doseljenog stanovništva: općina Baška (56,9\%), grad Krk (54,9\%), općina Dobrinj $(53,6 \%)$. Na razini cijelog otoka Krka 11,9\% stanovništva doselilo se iz drugoga naselja istoga grada/općine, 
44,8\% iz drugoga grada/općine Primorsko-goranske županije (najvjerojatnije je riječ o suburbanizaciji, odnosno preseljenju stanovništva iz Rijeke), a 23,3\% iz druge županije. Iz inozemstva se doselilo $19,4 \%$ stanovništva otoka. ${ }^{11}$

\section{OPĆE KRETANJE STANOVNIŠTVA}

Opće kretanje stanovništva obuhvaća prirodno kretanje i prostornu pokretljivost. Prema M. A. Friganoviću (1990), postoje četiri iseljenička (emigracijska) i jednako toliko imigracijskih tipova općega kretanja stanovništva. Određuju se na temelju odnosa popisne i prirodne promjene stanovništva. Svaki tip općega kretanja stanovništva prati određeni trend, koji je pri navođenju tipova napisan u zagradi. Iseljenički (emigracijski) tipovi jesu: E1 (emigracija), E2 (depopulacija), E3 (izrazita depopulacija) i E4 (izumiranje). Imigracijski tipovi jesu: I1 (eks-

(1) TABLICA 9

Opće kretanje stanovništva na otoku Krku po gradovima/općinama (1971. - 2011.) panzija imigracijom), I2 (regeneracija imigracijom), I3 (slaba regeneracija imigracijom) i I4 (vrlo slaba regeneracija imigracijom). Proučeno je opće kretanje stanovništva za gradove i općine otoka Krka od 1971. do 2011. (po međupopisjima).

\begin{tabular}{ccccc} 
& & & Grad/Općina & \\
\hline Baška Dobrinj & Krk & -Dubašnica- & Otok Krk \\
ukupnolj
\end{tabular}

\begin{tabular}{lrrrrrrrr}
\hline 1971. - 1981. & & & & & & & & \\
Popisna promjena & -129 & -295 & 332 & 250 & 259 & 94 & -287 & 224 \\
Prirodna promjena & -186 & -284 & 196 & 28 & 56 & -78 & -127 & -395 \\
Migracijska bilanca & 57 & -11 & 136 & 222 & 203 & 172 & -160 & 619 \\
Tip općeg kretanja & $\mathrm{I} 4$ & $\mathrm{E} 4$ & $\mathrm{I} 1$ & $\mathrm{I} 1$ & $\mathrm{I} 1$ & $\mathrm{I} 2$ & $\mathrm{E} 4$ & $\mathrm{I} 3$ \\
1981. -1991. & & & & & & & & \\
Popisna promjena & 17 & -5 & 1079 & 409 & 1488 & 163 & -83 & 3068 \\
Prirodna promjena & -149 & -283 & 265 & 75 & 174 & -58 & -96 & -68 \\
Migracijska bilanca & 166 & 278 & 814 & 334 & 1314 & 221 & 13 & 3136 \\
Tip općeg kretanja & $\mathrm{I} 3$ & $\mathrm{I} 4$ & $\mathrm{I} 1$ & $\mathrm{I} 1$ & $\mathrm{I} 1$ & $\mathrm{I} 2$ & $\mathrm{I} 4$ & $\mathrm{I} 2$ \\
1991.-2001. & & & & & & & & \\
Popisna promjena & 98 & 26 & 494 & 565 & 275 & 68 & -68 & 1458 \\
Prirodna promjena & -175 & -242 & 22 & 2 & 102 & -62 & -168 & -525 \\
Migracijska bilanca & 273 & 268 & 472 & 563 & 173 & 130 & 100 & 1983 \\
Tip općeg kretanja & $\mathrm{I} 3$ & $\mathrm{I} 3$ & $\mathrm{I} 1$ & $\mathrm{I} 1$ & $\mathrm{I} 1$ & $\mathrm{I} 2$ & $\mathrm{I} 4$ & $\mathrm{I} 2$ \\
2001.-2011. & & & & & & & & \\
Popisna promjena & 120 & 108 & 790 & 408 & -15 & 97 & 15 & 1523 \\
Prirodna promjena & -123 & -177 & -72 & -34 & 36 & -57 & -82 & -529 \\
Migracijska bilanca & 243 & 285 & 862 & 442 & -51 & 154 & 97 & 2052 \\
Tip općeg kretanja & $\mathrm{I} 3$ & $\mathrm{I} 3$ & $\mathrm{I} 2$ & $\mathrm{I} 2$ & $\mathrm{E} 2$ & $\mathrm{I} 2$ & $\mathrm{I} 3$ & $\mathrm{I} 2$ \\
\hline
\end{tabular}

Izvor: Smoljanović i sur. (2008), Stanovništvo hrvatskih otoka 2001., Popis stanovništva, kućanstava i stanova 2011. (http://www.dzs.hr); Vitalna statistika za pojedine godine 2001.-2011., DZS Republike Hrvatske.

Tipovi općega kretanja stanovništva na otoku Krku povoljniji su od onih za Hrvatsku u cjelini. Na temelju tipova opće- 
DRUŠ. ISTRAŽ. ZAGREB GOD. 22 (2013), BR. 1 STR. 167-193

JOVANIĆ, M., TURK, I.: PROMJENE U... ga kretanja stanovništva može se ustvrditi da otok Krk ulazi u pozitivan pol demografskog razvoja Hrvatske. Unatoč tome, zabrinjava činjenica da je u većini gradova/općina prirodna depopulacija prisutna dugi niz godina, pa je očito da je porast broja stanovnika na Krku uvjetovan imigracijom, koja je potaknuta razvojem turizma i blizinom Rijeke, s kojom je otok dobro prometno povezan (Krčki most). Najpovoljnije trendove općega kretanja stanovništva bilježi Grad Krk, gdje je smješteno najveće (istoimeno) naselje na otoku, koje nedvojbeno ima važnu centralnu ulogu. Općine u kojima je turizam razvijen načelno imaju bolje pokazatelje općega kretanja stanovništva od prometno izoliranijih općina u kojima turizam nije toliko važan.

\section{ZAKLJUČAK}

Naseljenost nekoga područja rezultat je interakcije različitih utjecaja (prirodno-geografskih, društveno-gospodarskih). U prošlosti i danas svaki prostor ima svoja obilježja u demografskom razvitku. Razmještaj naselja na otoku Krku neravnomjeran je. Na razvoj i promjene u naseljenosti otoka Krka, uz fizičko-geografske čimbenike, znatno su utjecali i društveno-geografski faktori (razvoj prometa, industrije i turizma). Uspostavom trajektnih linija, a posebice izgradnjom mosta, ranije izoliran otok postaje vrlo dobro povezan s kopnenim zaleđem. Upravo je prometna povezanost glavni preduvjet pojave i razvoja turizma, koji je danas glavna gospodarska grana otoka Krka. Razvoj turizma vrlo je pozitivno djelovao na demografske tokove na Krku.

Može se zaključiti da je smanjenje ukupnoga broja stanovnika otoka Krka od početka 20. stoljeća povezano s procesom urbanizacije grada Rijeke, dok je povećanje broja stanovnika otoka Krka od 70-ih godina 20. stoljeća povezano s procesom suburbanizacije istoga grada. Od sedamdesetih godina do danas zapadna i sjeverna strana otoka imaju pozitivnije demografske pokazatelje (indeks promjene broja stanovnika, vitalni indeks) od istočne i jugoistočne strane otoka. To se može objasniti boljim preduvjetima za razvoj turizma na zapadnoj strani otoka, odnosno razvojem industrije i većom blizinom Rijeke sjevernoj strani otoka. Prethodno navedeno implicira i objašnjava premještanje težišta naseljenosti od sredine 19. stoljeća do danas u smjeru sjeverozapada, a u skladu s tim je i elipsa naseljenosti za 2011. položena sjeverozapadnije od one za 1857. godinu. Gotovo su sva naselja povoljnijih demografskih pokazatelja povezana državnom cestom, što upućuje na veliku važnost dobre prometne dostupnosti. Naselja na obali imaju povoljnije demografske pokazatelje od onih u unutrašnjosti otoka, što svjedoči o jačanju lito- 
DRUŠ. ISTRAŽ. ZAGREB GOD. 22 (2013), BR. 1, STR. 167-193

JOVANIĆ, M., TURK, I.: PROMJENE U... ralizacije. Od popisa stanovništva iz 1971. do popisa iz 2011. popisna je promjena broja stanovnika otoka Krka pozitivna. Treba ipak imati na umu da u suvremenom demografskom razvoju postoji nesklad između popisnoga porasta broja stanovnika i procesa prirodne depopulacije, što dovodi do sumnje $\mathrm{u}$ vjerodostojnost rezultata najnovijih popisa stanovništva (popisivanje fiktivnoga stanovništva).

Otok Krk, za razliku od mnogih drugih jadranskih otoka, više nije depopulacijski prostor. Ipak, u unutrašnjosti otoka Krka postoje vrlo mala naselja (prema zadnjem popisu iz 2011. godine 16 naselja broji do 50 stanovnika) koja imaju nepovoljnu demografsku sliku. To je problem koji se može prevladati razvojem turizma i ekološke poljoprivrede u unutrašnjosti otoka.

${ }^{1}$ Hrvatske naseljene otoke s obzirom na njihovu udaljenost od kopna dijelimo na unutarnje (priobalne) i vanjske otoke. Unutarnjim (priobalnim) otocima pripadaju: Krk, Rab, Pag, Vir, Ugljan, Pašman, Vrgada, Murter, Prvić (kod Šibenika), Zlarin, Krapanj, Drvenik Mali, Drvenik Veli, Čiovo, Šolta, Brač, Šipan, Koločep i Lopud. Vanjskim otocima pripadaju svi ostali naseljeni hrvatski otoci (Nejašmić, 1992).

2 O koncepcijama popisa stanovništva može se pročitati u radovima: Nejašmić (1991); Lajić i Nejašmić (1994); Smoljanović, Smoljanović i Nejašmić (1999); Pokos (2003); Mišetić i Nejašmić (2004); Lajić i Mišetić (2006) i na službenim internetskim stranicama Državnoga zavoda za statistiku.

3 Riječ je o seriji od dvije knjige: 1) Smoljanović, A., Smoljanović, M. i Nejašmić, I., 1999: Stanovništvo hrvatskih otoka, Zavod za javno zdravstvo Županije Splitsko-Dalmatinske, Split i 2) Smoljanović, M., Smoljanović, A., Rudan, I., 2008: Stanovništvo hrvatskih otoka 2001, Laser Plus d.o.o., Split.

4 Ovo se posebno odnosi na popisne godine 1857., 1869. i 1880. gdje su prema podacima DZS-a neka naselja navedena bez stanovnika: 1857. i 1869. bez stanovnika su naselja Dolovo, Hlapa, Klimno, Rudine, Šilo i Žestilac, a naselje Klanice je bez stanovnika i popisne godine 1880 . Za razliku od toga, prema prethodno navedenim knjigama, svih 68 naselja otoka Krka bilo je naseljeno.

5 Godine 1905. osnovano je "Krčko parobrodarsko društvo" u Šilu, što je uzrokovalo porast broja stanovnika toga naselja. U Šilo se nisu doseljavali samo pojedinci nego su se doseljavale i cijele obitelji pojedinaca koji su bili povezani s radom društva. Iste godine počinje prometovati redovita parobrodarska linija koja dnevno održava vezu između istočnoga dijela otoka s naseljima vinodolske obale i s Rijekom.

${ }^{6}$ Treba napomenuti da su nakon 2. svjetskog rata optiranjem stanovništva za Italiju bila obuhvaćena sva naselja otoka Cresa, ali na otoku Krku tim je procesom bilo obuhvaćeno samo naselje Krk, koje je kasnijim neprekidnim priljevom otočnoga i vanjskoga stanovništva održalo svoje demografske okvire. 
DRUŠ. ISTRAŽ. ZAGREB GOD. 22 (2013), BR. 1

JOVANIĆ, M., TURK, I.: PROMJENE U... STR. 167-193

${ }^{7}$ Novosel-Žic (1987) navodi 14 priobalnih naselja (Baška, Čižići, Klimno, Kornić, Krk, Malinska, Njivice, Omišalj, Porat, Punat, Soline, Stara Baška, Šilo, Vrbnik), a Lajić i Mišetić (2006) izdvajaju još i naselje Zidarići (općina Malinska-Dubašnica), jer je svojim razvojem u zadnjih dvadesetak godina postalo priobalno. U ovom se radu služimo diferencijacijom novijega datuma (Lajić i Mišetić, 2006).

8 Proces migracije stanovništva iz unutrašnjosti otoka Krka prema obali prisutan je još od pedesetih godina 20. stoljeća. Njime je zahvaćen i Dobrinj - dio njegova stanovništva nastanilo se u Šilu, obalnom naselju, revitaliziranom nakon pojave trajekta 1959. Šilo je 1961. imalo 151 stanovnika, do 1981. poraslo je na 228 stanovnika (Novosel-Žic, 1986). Zatim tu je i primjer "spuštanja" naselja prema obali - naselje Kornić.

9 Vitalni indeks dobar je pokazatelj smjera (bio)reprodukcije. Ako je veći od 100, onda je posrijedi proširena bioreprodukcija stanovništva (broj stanovnika se povećava prirodnom promjenom), a ako je pak manji od 100, tada je to smanjujuća reprodukcija stanovništva (broj stanovnika smanjuje se prirodnom promjenom). Iznosi li vitalni indeks 100, posrijedi je prirodna stagnacija ili nulta stopa prirodne promjene (Nejašmić, 2005).

10 Sredinom 19. stoljeća Pula postaje glavna austrijska ratna luka, što uz izgradnju željezničke pruge prema Trstu i Beču znatno pridonosi gospodarskom jačanju grada. Istodobno, i u Rijeci se intenzivno razvijaju lučke funkcije, industrija i trgovina. Time Rijeka postaje glavna luka ugarskoga dijela Habsburške Monarhije i 1873. željeznicom se povezuje s Karlovcem, Zagrebom i Budimpeštom. Nasuprot njima, ostali promatrani hrvatski obalni gradovi značajniji razvoj doživljavaju tek nakon Drugoga svjetskog rata zahvaljujući urbano lociranoj industrijalizaciji te razvoju turizma i drugih tercijarnih djelatnosti pod utjecajem litoralizacije (Klempić Bogadi i Podgorelec, 2009).

11 Od toga 59,8\% iz BiH, 17,5\% iz Srbije i Crne Gore, 5,8\% iz Slovenije, 5,3\% iz Makedonije i 11,6\% iz ostalih država.

\section{LITERATURA}

Jovanić, M. (2011). GIS analiza promjena naseljenosti otoka Krka od sredine 19. stoljeća (Diplomski rad). Sveučilište u Zagrebu, Prirodoslovno-matematički fakultet, Geografski odsjek, Zagreb.

Klempić Bogadi, S. (2008). Utjecaj migracije na demografski razvoj riječke aglomeracije. Hrvatski geografski glasnik, 70(1), 43-65.

Klempić Bogadi, S. i Podgorelec, S. (2009). Sociodemografske značajke i procesi u hrvatskim obalnim gradovima. Geoadria, 14(2), 221-247.

Lajić, I. (2006). Kvarnerski otoci, demografski razvoj i povijesne mijene. Zagreb: Institut za migracije i narodnosti.

Lajić, I. i Mišetić, R. (2006). Otočni logaritam, aktualno stanje i suvremeni demografski procesi na jadranskim otocima. Zagreb: Institut za migracije i narodnosti, Ministarstvo mora, turizma, prometa i razvitka.

Lajić, I. i Nejašmić, I. (1994). Metodološke osobitosti demografskog istraživanja hrvatskog otočja. Društvena istraživanja, 3(4-5), 381-396.

Mišetić, R. i Nejašmić, I. (2004). Buduće kretanje broja stanovnika Hrvatske: projekcija 2001.-2031. Društvena istraživanja, 13(4-5), 751-776. 
DRUŠ. ISTRAŽ. ZAGREB GOD. 22 (2013), BR. 1, STR. 167-193

JOVANIĆ, M., TURK, I.: PROMJENE U...
Nejašmić, I. (1991). Depopulacija u Hrvatskoj - korijeni, stanje, izgledi. Zagreb: Globus i Institut za migracije i narodnosti Sveučilišta u Zagrebu.

Nejašmić, I. (1992). Promjene u dobno-spolnom sastavu stanovništva istočnojadranskog otočja (1953-1991). Acta Geographica Croatica, 27(1), 15-34.

Nejašmić, I. (1999). Uloga turizma u diferenciranom demografskom razvitku otočnih naselja: primjer srednjodalmatinskog otočja. Hrvatski geografski glasnik, 61(1), 37-52.

Nejašmić, I. (2005). Demogeografija: stanovništvo u prostornim odnosima i procesima. Zagreb: Školska knjiga.

Novosel, P. (1972). O nekim socijalno-populacijskim procesima otoka Krka nakon Drugog svjetskog rata. U: Zbornik IX. kongresa geografa Jugoslavije (str. 339-349). Sarajevo.

Novosel, P. (1975). Kretanje stanovništva otoka Krka od 1857-1971. godine. U: Krčki zbornik (sv. 6, str. 107-147). Krk.

Novosel, P. (1976). Neke osobitosti sastava stanovništva otoka Krka od 1857. do 1971. godine. Radovi, 13, 219-263.

Novosel-Žic, P. (1986). Neki pokazatelji centralnomjesne organizacije otoka Krka. Radovi, 21, 29-36.

Novosel-Žic, P. (1987). Od trajekta do mosta (socijalno-geografska transformacija). U: Krčki zbornik (sv. 17). Krk, Zagreb: Povijesno društvo otoka Krka i Savez geografskih društava Hrvatske.

Opačić, V. T. (2008). Vikendice na otoku Krku - prostorni raspored i strukturna obilježja vlasnika. Geoadria, 13(1), 41-80.

Pokos, N. (2003). Metodološke promjene u popisima stanovništva. Hrvatska revija, III(1), 29-35.

Smoljanović, M., Smoljanović, A. i Nejašmić, I. (1999). Stanovništvo hrvatskih otoka. Split: Zavod za javno zdravstvo Županije Splitsko-dalmatinske.

Smoljanović, M., Smoljanović, A. i Rudan, I. (2008). Stanovništvo hrvatskih otoka 2001. Split: Laser Plus d.o.o.

Stražičić, N. (1977). Mljet - primjer izoliranog otoka. Geografski horizonti, 1-2, 18-36.

Turk, H. (1994). Položaj i prirodna osnova otoka Krka kao čimbenici turističkog razvoja. U: Krčki zbornik (sv. 29, str. 11-31). Krk: Povijesno društvo otoka Krka i Turistička zajednica Općine Krk.

Valožić, L. (2007). GIS analiza promjena naseljenosti Istarske županije od 1948.-2001. (Diplomski rad). Sveučilište u Zagrebu, Prirodoslovno-matematički fakultet, Geografski odsjek, Zagreb.

Vojnović, F. (1993). Revitalizacija viškog otočnog prostora. Acta Geographica Croatica, 28, 113-136.

\section{IZVORI}

Službene internetske stranice DZS-a: Metodološke napomene, http://www. dzs.hr (10. 9. 2011.).

Službene internetske stranice DZS-a: Naselja $i$ stanovništvo Republike Hrvatske 1857.-2001., http://www.dzs.hr (10. 9. 2011.). 
DRUŠ. ISTRAŽ. ZAGREB GOD. 22 (2013), BR. 1 STR. 167-193

JOVANIĆ, M., TURK, I.: PROMJENE U...
Službene internetske stranice DZS-a: Metodološka objašnjenja popisa stanovništva 2001., http://www.dzs.hr/Hrv/censuses/Census2001/census_ met.htm (10. 9. 2011.).

Službene internetske stranice DZS-a: Popis stanovništva, kućanstava $i$ stanova 2011., Stanovništvo prema starosti $i$ spolu, po naseljima, http:// www.dzs.hr (17. 12. 2012.).

Službene internetske stranice DZS-a: Popis stanovništva, kućanstava $i$ stanova 2001.: Stanovništvo prema migracijskim obilježjima, po gradovima/općinama, http://www.dzs.hr (10. 6. 2012.).

Službene internetske stranice DZS-a: Statistički ljetopis 2009., http://www. dzs.hr/Hrv/publication/stat_year.htm (10. 9. 2011.).

Vitalna statistika (rođeni i umrli) u razdoblju 1964.-2011., podaci za pojedine godine, naseljski tablogrami, Državni zavod za statistiku, Zagreb.

\section{Changes in the Population Dynamics of the Island of Krk}

\author{
Marta JOVANIĆ \\ Vinkovci \\ Ivo TURK \\ Institute of Social Sciences Ivo Pilar, Zagreb
}

Population development on the islands is mostly conditioned by the distance from the mainland and by the means of transport connecting them with it. The aim of this work was to research the dynamics of certain demographic components of the Island of Krk. Namely, it analyses the changes of population of the Island of Krk from 1857 to 2011 . The analysis has shown that the decreasing number of inhabitants of the island from the early 20th century is correlated with the processes of urbanization of the town of Rijeka, while the increase of the number of inhabitants on the island from the 1970s onwards is related with suburbanization, which was significantly influenced by the construction of the Krk bridge. Since the 1970s, the west and north sides of the island have recorded more positive demographic indicators than the east and southeast sides. This can be explained by better conditions for the development of tourism on the west side of the island, and the proximity of Rijeka. Therefore, since the mid 19th century, the mean centre of population has shifted towards the northwest.

Keywords: population, mean centre of population, Island of Krk, demographic dynamics, ellipse of population, littoralisation 